\title{
SPECIFIC MODIFIERS OF EOSIN EYE COLOR IN DROSOPHILA MELANOGASTER ${ }^{1}$
}

\author{
CALVIN B. BRIDGES \\ Columbia University, New York City \\ TWO DIAGRAMS \\ CONTENTS
}

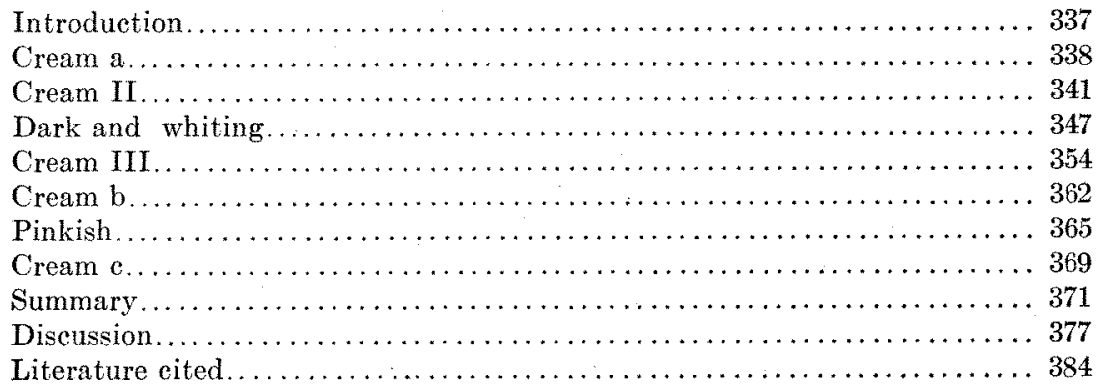

\section{INTRODUCTION}

The main significance of the material presented in this paper is in its bearing on the question of modifying genes and the correlated question of the method by which selection attains its results. A demonstration has been made of eight mutant genes which by themselves produce little or no effect upon the eye color of flies homozygous for them, yet which modify the eye color of the sex-linked mutant 'eosin.'2 These 'specific' modifications are clear and simple cases of multiple genes. Each is

${ }^{1}$ Contribution from the Zoological Laboratory of Columbia University, and the Carnegie Institution of Washington.

${ }^{2}$ A reference to the case of cream II and its bearing on the question of multiple and modifying genes has been made in "The Mechanism of Mendelian Heredity," page 203. A brief aceount of the discovery and the main facts of the inheritance of cream a, dark, whiting, and cream b has been given in "Non-disjunction as proof of the chromosome theory of heredity," Genetics 1, page $147 \mathrm{ff}$. The importance in evolution of specific modifiers, typified by cream a and whiting, was emphasized in "The Critique of the Theory of Evolution," pages 163 and 164. 
the result of the coaction of a specific modifying gene (cream a, $b$, etc.) and of a particular gene (eosin) which serves as a base or chief factor. The scale of the modifications of eosin produced by these several modifiers ranges on the one hand to a deep pink darker than eosin, and on the other hand to a pure white, without considering the effects of combinations of two or more modifiers. In origin these modifiers were entirely independent of one another, and the order of their occurrence bears only a random relationship to the dark-light seriation. By combination of several of these simple modifiers a multiple heterozygous stock could be obtained which would be amenable to selection and which would offer upon analysis a satisfactory parallel to such a case as that shown by Castle's hooded rats.

\section{CREAM A}

A pure stock of the sex-linked eye-color eosin shows a strong sexual bicolorism, that is, the eye color of the eosin female is a rather deep pink, only slightly yellowish, while the eye color of the eosin male is a pinkish yellow, much lighter in tone than the color of the female (see Morgan, '12, for an account of the origin of eosin and a colored plate showing this difference in color). Eosin females and males maintain this constant difference in color wherever they reappear after crossing, and all double recessives involving eosin, for example, eosin vermilion and eosin pink, are likewise bicolored (Morgan and Bridges, '13). Eosin is allelomorphic to white - an eosin female mated to a white male gives in $F_{1}$ no wild-type (red-eyed) daughters, but only daughters (white-eosin ${ }^{3}$ compounds) which are intermediate in color between white and eosin. The sons of this cross are of the regular light color, which happens to be the same as that of the whiteeosin female.

In carrying on the stock of non-disjunction, such a mating as that just described had been repeated through several generations when it was noticed (July 15, 1913) that the flies in one of these

\footnotetext{
${ }^{3}$ We denote compounds by the use of the hyphen and do not use the hyphen for non-allelomorphic multiples, for example, white-eosin, but eosin vermilion.
} 
cultures (n43, Bridges, '16, p. 147) were somewhat variable in eye color. Certain of the flies were lighter than normal, having markedly less of the pinkish tinge than standard eosin, so that they were of a pale yellow or 'cream' color. Some of the cream males were bred to rather light white-eosin sisters which were suspected of being creams also. This mass culture gave a considerable proportion of creams, though whites (males) and eosins were also present. Little effort was made to separate the several classes of females. Among the sons there was no confusion, there being the three classes, white, eosin, and the new light color, cream.

It was now assumed that the cream was a double recessive, that is, eosin plus a recessive mutant eye color, which by analogy with the known dilution effects produced on eosin by such light eye colors as vermilion and pink, was presupposed to be a color more transparent than the normal red of wild flies.

When an eosin male is outcrossed to a wild female, all the $F_{2}$ females are wild-type, but half of the males are eosin and the other half wild-type. If a cream male is an eosin male modified by an autosomal recessive mutant as suggested above, then in $F_{2}$ from such a cream male by wild female, the new color should appear in a fourth of each of the classes which occur in the above cross. The $\mathrm{F}_{2}$ females should be in the ratio of 6 wild-type $: 2$ with the new eye color, while the $F_{2}$ males should be 3 wild-type : 1 new color : 3 eosin : 1 'cream,' the double recessive.

TABLE 1

$P_{1}$, cream or $\times$ wild $q$; wilde $\% F_{1}$ wild-type $\% \times F_{1}$ wild-type $\sigma^{\top}$

\begin{tabular}{c|c||c|c|c}
\hline $1913,10 / 71$ & WILD-TXPE $~$ & WILD-TYPE $\sigma^{\prime}$ & EOSIN $\sigma^{\circ}$ & 'CREAM' $\sigma^{\prime \prime}$ \\
\hline I 113 & 104 & 47 & 44 & 14 \\
\hline
\end{tabular}

1 Date on which the culture began to hatch.

The $\mathrm{F}_{2}$ results of the cross of a cream male to wild female (table 1) showed that while the 'cream' character reappeared in $F_{2}$ in the expected proportion ( 1 in 16), none of the other flies differed in eye color from those expected in the $F_{2}$ from the simple 
cross of eosin by wild. That is, none of the $F_{2}$ females, all of which were not-eosin, showed a trace of dilution, and likewise all of the not-eosin males were perfectly normal in color. About one-quarter of the eosin males were modified in eye color and showed the cream color of the grandfather. It is evident that the assumption was correct that the character cream is a double recessive, the product of the action of a recessive autosomal gene added to the effect of the sex-linked gene eosin. However, this gene does not by itself produce any visible effect, as is proved by the fact that a quarter of the wild-type flies must have been homozygous for it (not eosin creams $s^{4}$ ) and yet all were of normal undiluted color. The case of cream a was the first in Drosophila for which such a relationship was shown, and the class of genes typified by cream a has been called specific modifiers. Such specific modifiers have since been found to be very frequent and underlay many of the difficult early cases which were amenable to selection.

The cream a gene is probably autosomal rather than sex-linked, as shown by the fewness of the creams; if the cream gene were sex-linked, then, because of the linkage between eosin and cream, from a quarter to nearly all of the eosin $\mathrm{F}_{2}$ males should have been modified to cream, the frequency depending on whether the locus of the cream gene were far from or close to that of eosin.

${ }^{4}$ It is our custom to name mutants on the basis of the change they produce from the type of the wild fly, but since in the case of cream the stock homozygous for the gene is indistinguishable from the wild stock, the name was given from the most striking characteristic, namely, the power to dilute eosin to 'cream.' This mutant was not called cream a (symbol $\mathrm{c}_{\mathrm{ra}}$ ) until after the appearance of a second cream whose gene was found to be in the second chromosome. This new cream was then called cream II (the Roman II designating the second chromosome) and the first cream was renamed eream a (the $a, b$ denoting simply relative order of discovery). For convenience in the further discussion of all these creams, the term 'cream' when referring to the character will indicate the double mutant form, eosin cream $\left(w^{e} \mathrm{w}^{e} \mathrm{c}_{\mathrm{r}} \mathrm{c}_{\mathrm{r}}\right.$ ), and in those infrequent cases in which we refer to flies homozygous for the cream gene, but not for eosin, the absence of the eosin character will be denoted by 'not-eosin' ( $W W c_{r} c_{r}$ or $W W^{e} c_{r} c_{r}$ ). 


\section{CREAM II}

Shortly after the discovery of the first cream (cream a) a second cream appeared (September 15, 1913) among the eosin males and females of a stock culture of lethal 2 . Wild-type females heterozygous for lethal 2 had been crossed to eosin miniature males, and the $F_{1}$ wild-type daughters again crossed to eosin miniature males. The mothers of the culture which gave the creams were therefore wild-type females heterozygous for eosin and miniature as well as lethal $2\left(\frac{w^{e}+m}{+1_{2}+}\right)$ while the fathers were eosin miniature. The cream males and females which appeared were much paler than cream a, though like cream a they were a light, translucent yellow with little or no pinkish tinge. ${ }^{5}$ None of the noteosin flies were different in color from normal red flies.

A careful examination of the stock of eosin miniature failed to show any flies that did not have the standard eosin eye color and no lighter eye color has ever subsequently shown itself in this stock. It is evident that the gene for the modification had been present in the wild-type flies of the lethal 2 stock, but had been unsuspected so long as eosin was not present as a base. The demonstration that the cause of the observed dilution of eosin was a gene behaving in inheritance like the other mutant genes was easily made.

One of these cream males was outcrossed to a wild female. Among the $\mathrm{F}_{2}$ flies the creams reappeared, and, as in the parallel case of cream a, the not-eosin flies were all indistinguishable from one another and from wild flies in color. The $\mathrm{F}_{2}$ result resembled that obtained with cream a, except that, as stated, the new cream was considerably paler; and it was further discovered that besides the creams approximately 50 per cent of the eosin males were intermediates between eosin and this cream, that is, cream II diluted eosin even in heterozygous form, so that the eosin sons were visibly as well as genetically in the ratio 1 eosin $: 2$ eosin

${ }^{5}$ Colored figures of the unmodified eosin, and of cream II, of cream $b$, and of pinkish are being published by Bridges and Morgan in Carnegie Publication no. 287. 
heterozygous for cream II : 1 eosin pure for cream II. The entire ratio, disregarding sex, approximated $12: 1: 2: 1$, the 12 being the red-eyed flies.

From the $\mathrm{F}_{2}$ a few cream males were selected and bred to their sisters, all of which were wild-type in appearance, though a quarter of them were homozygous for the cream gene (not-eosin creams). This mass culture gave the expected cream females and males from which a pure breeding stock was made up. There was a difference in the color of the males and females of this pure stock, the difference being of the same order as the normal bicolorism of eosin. A complete separation of the eosin from the eosin heterozygous for cream had not been attempted in the original $\mathbf{F}_{2}$ culture. In order to observe the heterozygous condition more closely, a cream male from the pure stock was outcrossed to an eosin female. The $F_{1}$ flies, both males and females (culture M688) intermediate males 73 , intermediate females $88,{ }^{6}$ were lighter in eye color than standard eosin, though the difference between eosin and these heterozygotes was less than the difference between the heterozygotes and the pure cream.

Among these $\mathrm{F}_{2}$ offspring (table 2) there were six different eye colors: among the males the same three that occurred in the original $F_{2}$ and among the females three colors which, though corresponding genetically to the classes among the males, were darker in eye color. The cream female is lighter than the normal eosin male, while the heterozygous cream female is somewhat darker than the eosin male. In order from the darkest (a deep slightly yellowish pink) to the lightest (a pale translucent yellow) the six

${ }^{\circ}$ One of the 88 intermediate daughters had only three segments to her abdomen instead of the usual five. This female (figured by Morgan, '15, p. 425, text figure $3 a$ ) was the founder of a new type of abnormal segmentation of the abdomen -'patched.' The segments were reduced in number (as in the first specimen) or more typically were cut sharply into oblique or triangular pieces which were patched together as illustrated in Morgan's figures b-f. This character was recessive, but it generally reappeared in very much less than a quarter of the $F_{2}$ offspring. The usual causes for such deficiencies are poor viability, partial or complete dependence for realization on the coaction of one or more other genes, or failure to be developed in all the flies genetically pure for the gene, whether from environmental differences or because the normal fluctuations of the character overlap the wild-type. 
colors are: eosin female, heterozygous cream female, eosin male, heterozygous cream male, cream female, cream male (diagram 1, page 273). The females were first separated from the males. Then in each sex the pure ereams were separated from the others, and finally the more difficult separation of heterozygous cream from eosin was undertaken. The separation of the creams from other colors is accurate, but the final separation, that of the heterozygous creams from the eosins must be regarded as only a close approximation. The sharp $1: 2: 1$ ratio $(160: 318: 148)$ which was obtained from this separation probably represents among the eosins a fair number of the darkest heterozygotes, while the lightest of the pure eosins were likewise classified among

TABLE 2

The $F_{2}$ offspring given by $F_{1}$ pairs from the cross of a cream II male to an eosin female

\begin{tabular}{|c|c|c|c|c|c|c|}
\hline \multirow[b]{2}{*}{$1913,12 / 8$} & \multicolumn{3}{|c|}{ FEMALES } & \multicolumn{3}{|c|}{ MALES } \\
\hline & Eosin & $\begin{array}{c}\text { Heterozy- } \\
\text { gous } \\
\text { oream }\end{array}$ & Cream & Eosin & $\begin{array}{l}\text { Heterozy- } \\
\text { gous } \\
\text { cream }\end{array}$ & Cream \\
\hline M77. & 30 & 57 & 29 & 29 & 46 & 25 \\
\hline M78. & 19 & 49 & 16 & 14 & 30 & 15 \\
\hline M79. . & 23 & 43 & 19 & 18 & 34 & 20 \\
\hline M95. . & 14 & 32 & 11 & 13 & 27 & 13 \\
\hline Total.... & 86 & 181 & 75 & 74 & 137 & 73 \\
\hline
\end{tabular}

the heterozygotes. Probably 10 per cent of the combined eosin and heterozygous cream class overlapped enough so that the separations might or might not correspond to genetic differences. One test of the correctness of the classification of intermediates was made. From culture M79 a heterozygous male and a heterozygous female were selected, and the results (culture M95) showed that both individuals were of the supposed type.

No attempt has been made to secure a stock homozygous for the cream gene but without eosin. The cultures and experiments in which such not-eosin creams must have constituted one-fourth of the wild-type flies prove that such a stock could not be distinguished by inspection from a wild stock. 
That the action of cream II is specific only to eosin was suggested by crosses of cream with vermilion ( $\mathrm{x}$ chromosome) and with pink (third chromosome). A careful examination of the $F_{2}$ flies from these crosses showed no dilution of ether vermilion or pink by the cream, that is, the double recessive vermilion cream and pink cream (not-eosin) are indistinguishable from vermilion and pink, respectively.

The proper method of study for cases of multiple factors or of modifiers is by means of linkage experiments, whereby all guesswork as to the number and effect of modifiers can be eliminated. In Drosophila such a study is rendered particularly easy by the small number of chromosomes and by the fact that in the male there is no crossing over of any of the chromosomes. In consequence, if two recessive genes which belong to the same chromosome, for example, black and vestigial of the second chromosome, enter the cross from opposite parents ('repulsion') the $F_{2}$ never shows flies which have both these mutants at the same time. The double recessive class is entirely unrepresented, and the $2: 1: 1: 0$ ratio of 'absolute repulsion' results. This ratio holds whatever may be the amount of crossing over in the female, for the lack of double recessive sperm prevents the double recessive eggs from revealing themselves. This ratio is in marked contrast to the $9: 3: 3: 1$ ratio which obtains when the two genes belong to different chromosomes, for example, curved of the second chromosome and ebony of the third chromosome.

The light color cream was known to be eosin plus a recessive modifier which belonged to an autosome linkage group. To find whether this group was that of the second chromosome, a cream male (from pure stock) was outcrossed to a curved female, curved being a recessive wing character whose gene is known to belong to the second chromosome (Bridges and Sturtevant, '14). A pair of $F_{1}$ wild-type flies inbred gave the results of table 3 .

Since cream only shows itself where eosin is already present, we may disregard all the flies of culture 70 except those with eosin eyes. These eosin flies are obviously in the ratio $2: 1: 1: 0$ which is expected if the cream gene is in the second chromosome, though the flies a troeo few to prove the point. 
TABLE 3

$F_{2}$ from the cross of cream II male to curved fomale

\begin{tabular}{l|c|c|c|c|c|c}
\hline $1914,2 / 20$ & \multicolumn{2}{|c|}{ NoT-EOsin $\left(0^{\top}+\varphi\right)$} & \multicolumn{4}{|c}{ EOsIN (MaLES ONLY) } \\
\cline { 2 - 6 } & Wild-type & Curved & Eosin & Eosin curved & Cream II & $\begin{array}{c}\text { Cream II } \\
\text { curved }\end{array}$ \\
\hline 70 & 155 & 63 & 37 & 14 & 15 & 0 \\
\hline
\end{tabular}

A more efficient experiment than this last was carried out by making all the flies of the experiment eosin, in which case the $2: 1: 1: 0$ ratio involved all the offspring, rather than only a quarter as in culture 70. A stock of eosin black was made up (black being a second chromosome mutant) and a female of this stock was outcrossed to a cream II male. The $\mathrm{F}_{1}$ and $\mathrm{F}_{2}$ results are given in table 4 . All of the $F_{1}$ flies and half the $F_{2}$ flies were of the intermediate color of the heterozygous cream. In the $\mathrm{F}_{2}$ these intermediates were classified along with the pure eosins so that the cream was treated as though a strict recessive.

The $F_{2}$ ratio of $442: 217: 207: 0$ is a very close approximation to a $2: 1: 1: 0$ ratio and proves that the gene for cream is in the second chromosome (cream II).

TABLE 4

$P_{1}$ mating, cream $I I$ o $\times$ eosin black $q ; F_{1}$ mating, heterozygous cream $I I \% \times F_{1}$ heterozygous cream $I I$ of

\begin{tabular}{|c|c|c|c|c|c|c|c|c|}
\hline F) CULTURes $1914,3 / 16$ & \multicolumn{4}{|c|}{ HETEROZYGOUS CREAM II $q q$} & \multicolumn{4}{|c|}{ HETEROZYGOES CREAM II $\sigma^{7} \sigma^{7}$} \\
\hline 119 & \multicolumn{4}{|c|}{51} & \multicolumn{4}{|c|}{41} \\
\hline 329 & \multicolumn{4}{|c|}{15} & \multicolumn{4}{|c|}{18} \\
\hline Total:. & \multicolumn{4}{|c|}{66} & \multicolumn{4}{|c|}{59} \\
\hline \multirow{2}{*}{$F_{2}$ CELTERES $1914,8 / 3$} & \multicolumn{2}{|c|}{ Eosry } & \multicolumn{2}{|c|}{ EOSIN BLACX } & \multicolumn{2}{|c|}{ CrEAM II } & \multicolumn{2}{|c|}{ BLACK CREAM II } \\
\hline & \% & $a^{7}$ & $q$ & $\%$ & q & $0^{\pi}$ & $q$ & $0^{\pi}$ \\
\hline 372 & 50 & 38 & 24 & 15 & 14 & 25 & 0 & 0 \\
\hline 398 & 57 & 42 & 18 & 31 & 19 & 19 & 0 & 0 \\
\hline 399 & 69 & 79 & 36 & 43 & 43 & 39 & 0 & 0 \\
\hline 400 & 48 & 59 & 33 & 17 & 24 & 24 & 0 & 0 \\
\hline \multirow{2}{*}{ Totals. } & 224 & 218 & 111 & 106 & 100 & 107 & 0 & 0 \\
\hline & \multicolumn{2}{|c|}{442} & \multicolumn{2}{|c|}{217} & \multicolumn{2}{|c|}{207} & \multicolumn{2}{|c|}{0} \\
\hline
\end{tabular}


A similar experiment in which cream was crossed to eosin ebony (ebony being a third chromosome mutant, Sturtevant, '14) gave a typical $9: 3: 3: 1$ ratio (table 5), which agrees with the fact that the cream gene is not in the third chromosome.

In order to find the locus of cream within the second chromosome, it would have been necessary to run linkage experiments in which all the flies were eosin; thus, one of the experiments might have been cream II by eosin black and a backcross of the $F_{1}$ female to black cream males, and another a similar backcross in which curved was used in place of black. The amount of crossing over between black and curved was known to be about 25 per cent. The two values black cream and curved cream which would be found by two such experiments (both values might, of

TABLE 5

$F_{2}$ from the cross of cream II of by eosin ebony 우

\begin{tabular}{c|c|c|c|c}
\hline $1914,3 / 31$ & vosIN & CREAM II & EOSIN EBONY & CREAM II EBONY \\
\hline 154 & 61 & 21 & 18 & 4 \\
161 & 85 & 28 & 35 & 14 \\
162 & 134 & 37 & 36 & 10 \\
\hline Total........ & 280 & 86 & 89 & 28 \\
\hline
\end{tabular}

course, be found from a single more complicated experiment) would enable the locus of cream to be calculated with considerable accuracy. While much is to be learned of the mechanism of crossing over from a study of the relative distributions of loci within various regions of the chromosome, yet in the case of cream II it was thought that the compensation would not be worth the effort. Any further use of cream II in other linkage experiments would involve the 'eosinization' of all the stocks used. In the case of certain of the later creams, an approximate location of the gene within the chromosome has been made, but such location was made less laborious by the discovery of certain dominant mutations which were not available at the time the work on cream II was finished. 


\section{DARK AND WHITING}

It was noticed (September 23, 1913) that in certain cultures (м 100, м 101) which were part of the experiments on non-disjunction, there were present eosin males which were abnormally dark in color. In the next generation more dark males appeared and some of the white-eosin exceptional daughters were nearly as dark as pure eosin females (no pure eosin females could occur in this culture except by the very rare equational non-disjunction; Bridges, '16). In subsequent generations the dark modification continued to reappear in such manner and in such proportions as to suggest that it was a converse case to that of cream a, that is, that there was present a recessive gene, a specific darkener of eosin, which does not modify the color of those flies which are not eosin. No very extensive records of the behavior of dark were

TABLE 6

The occurrence of whiting among the offspring of a pair of 'dark' eosin flies

\begin{tabular}{|c|c|c|c|c|}
\hline $1913,11 / 21$ & $\operatorname{Eosin} 8$ & Eosin $0^{7}$ & whres $1 ! 9$ & WHITE $! ! 0^{*}$ \\
\hline M67. & 76 & 56 & 11 & 27 \\
\hline
\end{tabular}

made, since my attention was soon diverted from this type by the occurrence in the same cultures of a much more striking variation.

One of the dark females, supposed to be a white-eosin compound, mated to a dark eosin brother gave a surprising result in that there were produced some females which were pure white in eye color (table 6). When these white females began to appear they were set down as examples of equational non-disjunction, but as the culture produced more and more of them it was seen that they were appearing in far too great a proportion to be easily explained by this rare phenomenon. Again, if the mother of M67 were indeed heterozygous for the sex-linked white, then the white sons should be equal to the eosin sons in number, instead of which they were only about half as numerous. Furthermore, half of the daughters should be pure eosin and half the lighter whiteeosin compound, while in fact they seemed all to be pure eosin 
with many of them of an extra dark color. This extra dark color likewise occurred in a fair proportion of the eosin sons. The whole result of culture M67 seemed inexplicable unless it was assumed that the white which here appeared was not the original sex-linked white which had been running through the experiments up to this point, but was a new and complex color.

The disappearance of the true white is easily accounted for when one remembers that the culture from which this supposed whiteeosin female was drawn was extraordinarily complicated as to eyecolors by the presence of eosin and 'dark' eosin, of white-eosin compounds and of 'dark' white-eosin compounds, of the true white and of the new complex white, and as to inheritance by the occurrence in the same culture of two sex-linked and of two nonsex-linked characters, by the multiple allelomorphism of white and eosin and by the occurrence of exceptions by non-disjunction. Because of the dark modification it had been impossible to distinguish between the normal eosin color and a white-eosin compound raised to about this same color by the action of the dark modifier, and the mother chosen had really been pure eosin and not a dark white-eosin compound as supposed.

The true nature of the new white was not fully established until one of the white females from M67 was outcrossed to a bar male with the result shown in table 7 . Here the surprising fact came to light that the white female when outcrossed gave no white sons, and the 'exceptional' daughters likewise were not white, but were eosin. These facts prove that the white mother did not carry the sex-linked white, but was a modification of eosin, and that the modifier was an autosomal recessive. These conclusions were confirmed in the clearest fashion in the next generation by the offspring of culture M92 whose parents were a regular bar daughter and an 'exceptional' bar son both from M74 (table 7).

The colorless flies reappeared only among those sons which were already eosin, while the not-eosin flies, both males and females, showed no effect whatever of the action of the modifying gene. The $\mathrm{F}_{2}$ was a good example of a $12: 3: 1$ ratio. The new gene then differs from the two creams and dark only in this 
respect, that the double recessive eosin 'whiting' is pure white in eye color instead if being a pale yellow. Whiting, though much more extreme in its effects than cream II, was found to be completely recessive, the eosin males heterozygous for whiting were indistinguishable from the pure eosin males.

The results of these last two generations show conclusively that there was no sex-linked white present, and this proves that the colorless flies of the former culture M67 were likewise (eosin) whiting, the 132 eosin to 38 colorless flies of M67 being an approximation to the $3: 1$ ratio expected for a Mendelian recessive.

TABLE 7

The $F_{1}$ offspring of a white! ! \& from M67 which was outcrossed to a bar male

\begin{tabular}{|c|c|c|c|c|}
\hline \multirow{2}{*}{$1913,12 / 10$} & \multicolumn{2}{|c|}{ REGULAR OFFSPRING } & \multicolumn{2}{|c|}{ EXCEPTIONS BY NON-DISIUNCTION } \\
\hline & Bar 우 & Eosin o & Eosin 9 & Bar or \\
\hline M74. & 95 & 81 & 7 & 3 \\
\hline
\end{tabular}

The $F_{2}$ results obtained from a bar o and a bar of from the above; the bar character has been ignored

\begin{tabular}{c|c|c|c|c}
\hline $1913,12 / 27$ & $\operatorname{Red} \%$ & $\operatorname{Red} \sigma$ & Eosin $\sigma^{\pi}$ & Wbite !1 \\
\hline $\mathrm{M} 92 \ldots \ldots \ldots \ldots$ & 217 & 111 & 64 & 24 \\
\hline
\end{tabular}

The $F_{3}$ results obtained from a.red female and a white! I from the above

\begin{tabular}{|c|c|c|c|}
\hline $1914,1 / 21$ & Wild-type & Eosin & White!! \\
\hline $\operatorname{M114}\left\{\begin{array}{l}q \ldots \ldots \ldots \ldots \ldots \ldots \ldots \ldots \ldots \\
\sigma^{\prime} \ldots \ldots \ldots \ldots \ldots \ldots \ldots\end{array}\right.$ & $\begin{array}{l}44 \\
35\end{array}$ & $\begin{array}{l}24 \\
22\end{array}$ & $\begin{array}{l}26 \\
29\end{array}$ \\
\hline Total. & 79 & 46 & 55 \\
\hline
\end{tabular}

None of the females of culture M92 were eosin and accordingly none could show whiting. In order to obtain whiting females with which to make up a pure stock of whiting, several of the wild-type daughters were bred to their whiting brothers. A quarter of these wild-type daughters must have been pure for the whiting gene, a half heterozygous, and the remaining quarter free from it. One such selected female proved to be heterozygous for both eosin and whiting, and the cross of this female to the whiting brothers was thus a backcross test (table 7 ). 
Expectation called for an equality of the four genetic classes which occurred in culture M114, but as the not-eosin whiting males and females are indistinguishable from the wild-type flies, the $1: 1: 1: 1$ ratio became converted into a $2: 1: 1$ ratio. From the whiting females and males which appeared in culture M114 a pure stock of whiting was made up. This double recessive stock was indistinguishable in appearance from the stock of the sex-linked white.

Two of the whiting males of culture M114 were tested by outcrossing to eosin females. The $F_{1}$ flies were standard eosin in color (table 8), and the $F_{2}$ raised from two pairs of these $F_{1}$ flies

TABLE 8

The $F_{1}$ and $F_{2}$ results from the outcrossing of two whiting males of culture $M 114$ to eosin females of piure stock

\begin{tabular}{|c|c|c|c|c|}
\hline $1914,1 / 27$ & \multicolumn{2}{|c|}{ gosin $q$} & \multicolumn{2}{|c|}{ EOBIN or } \\
\hline $\begin{array}{l}\text { M118........... } \\
\text { M118.1......... }\end{array}$ & \multicolumn{2}{|c|}{$\begin{array}{l}64 \\
38\end{array}$} & \multicolumn{2}{|c|}{$\begin{array}{l}66 \\
35\end{array}$} \\
\hline Total........ & \multicolumn{2}{|c|}{102} & \multicolumn{2}{|c|}{101} \\
\hline $1914,2 / 9$ & EOBIN 9 & EOSIN $\sigma^{x}$ & waitiNG $\&$ & WHITING $0^{7}$ \\
\hline $\begin{array}{l}25 \\
26\end{array}$ & $\begin{array}{l}118 \\
118\end{array}$ & $\begin{array}{l}120 \\
104\end{array}$ & $\begin{array}{l}50 \\
53\end{array}$ & $\begin{array}{l}61 \\
53\end{array}$ \\
\hline Total......... & 236 & 224 & 103 & 114 \\
\hline
\end{tabular}

was of the ordinary $3: 1$ type, the whiting reappearing among the females and males equally (table 8 ). It is evident that whiting has excellent viability, for in most of these cultures it slightly exceeds expectation, the greatest departure being in the above cases where it reappeared as 32 instead of 25 per cent of the $F_{2}$ flies.

The sex-linked genes white, eosin, and cherry are all allelomorphs of each other. Cherry and eosin females are almost identical in color, but cherry males are of the same color as cherry females and are easily separated from eosin males. A series of tests was run to observe the effect of the whiting gene when acting with these allelomorphs. The previous experiments in which 
homozygous whiting had no visible effect in the absence of eosin have proved that red, the normal allelomorph of white, eosin and cherry, is unaffected.

In order to observe the interaction of white and whiting, two (eosin) whiting males from M114 were out-crossed to white females of pure stock. The $F_{1}$ females were white-eosin compounds of normal color, and the sons were white as expected (table 9). $\quad F_{2}$ from the cross of eosin male by white female gives in equal numbers the four classes: white-eosin $o$, white $o$, eosin $o^{x}$, and white $o^{x}$. The cross of (eosin) whiting

TABLE 9

The $F_{1}$ and $F_{2}$ offspring from the cross of (eosin) whiting males to white females

\begin{tabular}{|c|c|c|c|c|c|c|c|c|}
\hline \multicolumn{3}{|c|}{$1914,1 / 20$} & \multicolumn{3}{|c|}{ WHITE-EOSIN 9} & \multicolumn{3}{|c|}{ WHite $0^{\pi}$} \\
\hline \multicolumn{3}{|c|}{$\begin{array}{l}\mathrm{M} 101 \ldots \ldots \ldots \ldots \ldots \ldots \ldots \ldots \ldots \\
\mathrm{M} 117, \ldots \ldots \ldots \ldots \ldots \ldots\end{array}$} & \multicolumn{3}{|c|}{$\begin{array}{r}113 \\
46\end{array}$} & \multicolumn{3}{|c|}{$\begin{array}{r}107 \\
46\end{array}$} \\
\hline \multicolumn{3}{|l|}{ Total. } & \multicolumn{3}{|c|}{159} & \multicolumn{3}{|c|}{153} \\
\hline $1914,2 / 3$ & $\begin{array}{l}\text { WHITE- } \\
\text { BOSIN }\end{array}$ & $\begin{array}{c}\text { (WHITB- } \\
\text { EOSIN) } \\
\text { WHITING }\end{array}$ & WHITE $?$ & $\left|\begin{array}{c}\text { WHITE } \\
\text { (WHTTMN }) \\
q\end{array}\right|$ & EOSIN $0^{7}$ & $\begin{array}{c}\text { (EOSIN) } \\
\text { WHITINGO }\end{array}$ & WHITE o & 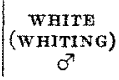 \\
\hline 9 & 44 & & 81 & & 54 & & 75 & \\
\hline 31 & 37 & & 65 & 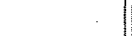 & 24 & & 55 & \\
\hline 32 & 18 & & 21 & - & 25 & & 28 & \\
\hline Total... & 99 & & 167 & & 103 & & 158 & \\
\hline
\end{tabular}

male by white female should give this same result with the further genetic subdivision of each of the four classes into 3 notwhiting to 1 homozygous for whiting. Since all white flies are incapable of further dilution the white whiting double recessive should be white even in the absence of effect of whiting on white. But in the white-eosin compound females we shall have a chance to observe the interaction of white and whiting. If white and eosin react in the same fashion toward the whiting gene, then the substitution of one white allelomorph for one eosin in the white-eosin compound should not prevent the whiting from diluting the compound to a colorless eye. But if the white cannot thus be substituted, the white-eosin compound should 
be either unaffected or less affected by the action of the whiting gene. Should the white-eosin whiting flies be colorless, then the colorless classes should be 3 white +1 whiting white +1 eosin whiting (eosin whiting if males, white-eosin whiting if females), and these classes should total $\frac{5}{8}$, or 62.5 per cent. The colorless flies did in fact constitute 61.7 per cent. What is even more significant, the proportion of colorless flies among the females was just as great as among the males (table 9). The colorless males are known to include the (eosin) whiting flies, and the conclusion is justified that the like class of colorless females included white-eosin whiting flies.

TABLE 10

The $F_{1}$ and $F_{2}$ offspring from the outcross of (eosin) whiting males to cherry female

\begin{tabular}{|c|c|c|c|c|c|c|c|c|}
\hline \multicolumn{3}{|c|}{$1914,1 / 28$} & \multicolumn{3}{|c|}{ EOSIN-CHERRY $申$} & \multicolumn{3}{|c|}{ CHERRY O } \\
\hline \multicolumn{3}{|l|}{ M119. } & & \multicolumn{2}{|l|}{64} & \multicolumn{3}{|c|}{75} \\
\hline \multicolumn{3}{|l|}{ Total. } & \multicolumn{3}{|c|}{128} & \multicolumn{3}{|c|}{138} \\
\hline $1914,2 / 9$ & $\begin{array}{l}\text { EOSIN- } \\
\text { CHARRYY }\end{array}$ & $\left|\begin{array}{c}\text { DOsIN- } \\
\text { CHERRX } \\
(\text { WHITING) } \\
\varnothing\end{array}\right|$ & CHERRY & $\left|\begin{array}{c}\text { CHERRY } \\
\text { (WHTRNQ }) \\
q\end{array}\right|$ & $\operatorname{EOSTN} \sigma^{\pi}$ & $\begin{array}{c}\text { (EOSIN) } \\
\text { WHITING } \\
0^{7}\end{array}$ & CHERRY of $^{7}$ & {$\left[\begin{array}{c}\text { CHERRY } \\
\text { (WHITING) } \\
\sigma^{\pi}\end{array}\right.$} \\
\hline 27 & \multicolumn{4}{|c|}{159} & 64 & 12 & \multicolumn{2}{|c|}{93} \\
\hline 28 & \multicolumn{4}{|c|}{169} & 48 & 24 & \multicolumn{2}{|c|}{73} \\
\hline Total.. & \multicolumn{4}{|c|}{328} & 112 & 36 & \multicolumn{2}{|c|}{166} \\
\hline
\end{tabular}

The most interesting of these three experiments was that in which (eosin) whiting males were outcrossed to cherry females. The $F_{1}$ females were eosin-cherry compounds, and the males were cherry which is of nearly the same color (table 10). $\quad F_{2}$ of the cross of eosin male by cherry female gives in equal numbers the $\mathrm{F}_{2}$ classes eosin-cherry compound of, cherry $q$, cherry $\sigma^{\text {t }}$, and eosin $\sigma^{x}$. The eosin-cherry female and the pure cherry female are so nearly the same color that they form one phenotype, but the eosin males can be easily separated from the cherry males. The cross of (eosin) whiting male by cherry female will give further subdivisions of each of these classes into 3 notwhiting: 1 homozygous for whiting. 
The result obtained in this $F_{2}$ was entirely unexpected; for cherry, which is allelomorphic to eosin and so closely similar as to be distinguishable only in the males, gave a totally dissimilar reaction with whiting, the double recessive, cherry whiting, being indistinguishable from cherry both in males and females (table 10). This result is very clearly shown by the males of this $F_{2}$ which closely approach the ratio $4: 3: 1$. A corresponding condition is revealed in the females, for not a single colorless female occurred, and though the females were of four main genetic types they were objectively of but a single class. The whole ratio in this $\mathrm{F}_{2}$ was then 12:3:1 exactly as would be the case in the $F_{2}$ from an outcross of (eosin) whiting male by wild female; that is, cherry is similar to the wild-type allelomorph red in its interaction with the whiting gene. It was observed in the $F_{2}$ from (eosin) whiting by white that the eosin-white whiting female is colorless; in this experiment we observe that the eosin-cherry whiting female is not thus diluted. This comparison shows that there is here a total dissimilarity in the reaction of the allelomorphs white and cherry. The fact that cherry whiting is indistinguishable from cherry proves a like dissimilarity of the allelomorphs eosin and cherry. The entire group of experiments reveal how curiously specific whiting is in its power of dilution, giving with eosin and with white the extreme amount of dilution, and with red and with cherry the other extreme of dilution-no dilution whatever.

One further test of the lack of reaction of whiting with cherry was made without the presence of eosin in the cross. The $F_{1}$ cherry males from the cross of cherry female by (eosin) whiting sp. male were heterozygous for the whiting gene. One of these males was outcrossed to pure cherry females and from the $F_{1}$ cherry males and females two mass cultures were made (table 11). One-sixteenth of the flies hatching from these new cultures should be whiting as well as cherry, while the eosin has been entirely eliminated. None of the 678 cherry flies from these cultures was diluted, a result which confirms the conclusion that the double recessive cherry whiting is not visibly different from cherry. 
TABLE 11

The $F_{2}$ offspring of two $F_{1}$ mass cultures from the outcross of an $F_{1}$ cherry male heterozygous for whiting (ex M119) to cherry female

\begin{tabular}{|c|c|c|}
\hline $1914,3 / 2$ & $\begin{array}{c}\text { CHERRY AND CHERRY } \\
\text { (WHITING) } q \varnothing\end{array}$ & $\begin{array}{l}\text { CRERRY AND GHERR } \\
\text { (WHITING) ơ } 0^{7}\end{array}$ \\
\hline 75 & 215 & 241 \\
\hline 95 & 118 & 104 \\
\hline Total................. & 333 & 345 \\
\hline
\end{tabular}

\section{CREAM III}

In a culture which was part of an experiment on lethal $1 \mathrm{~b}$ (Morgan and Bridges, '16) Miss E. M. Wallace found (February $27,1914)$ a few females which were much lighter in eye color than their white-eosin sisters. Following my suggestion that this color might be a cream similar to cream a or cream II, these females were given me for experimentation. I outcrossed one of them to an eosin male of pure stock. The $\mathrm{F}_{1}$ males (table 12) showed that this female had carried yellow and white in one $\mathrm{X}$ and eosin in the other, this being the condition expected from her parentage. The cream was seen to be recessive, since all of the $\mathrm{F}_{1}$ flies were standard in color, and not sex-linked, since it did not appear in the sons of the cream mother.

An $\mathrm{F}_{1}$ mating was made between an eosin female and an eosin male, since by this means both yellow and white could be eliminated from the experiment. In $\mathrm{F}_{2}$ the cream color reappeared but in numbers rather fewer than the expected quarter (table 12). In appearance this cream III was very nearly as light as the homozygous cream II.

TABLE 12

The $F_{1}$ and $F_{2}$ offspring from the outcross of a new cream (cream III) of to an $\operatorname{cosin} \sigma^{7}$

\begin{tabular}{|c|c|c|c|c|c|c|c|}
\hline $1914,3 / 9$ & $\begin{array}{r}\text { waITE- } \\
\text { q }\end{array}$ & BOSIN o & $\begin{array}{l}\text { YEILLOW } \\
\text { WEITE } \sigma^{x}\end{array}$ & $\operatorname{mosin} a^{7}$ & YELLC & $\sigma^{x} \operatorname{mos} x$ & WHITE O \\
\hline 92 & 25 & 21 & 15 & 24 & & 0 & 0 \\
\hline \multicolumn{2}{|c|}{$1914,3 / 26$} & EOSIN $?$ & $\operatorname{mos} I N \theta^{x}$ & \multicolumn{3}{|c|}{ CREAMIII $\%$} & IEAM III $0^{\pi}$ \\
\hline \multicolumn{2}{|c|}{136} & 91 & 92 & \multicolumn{3}{|c|}{22} & 21 \\
\hline
\end{tabular}


From the cream males and females of culture 136 a pure stock of the double recessive easin cream was made up. This double recessive will usually be referred to simply as cream, and 'noteosin' will be used in other cases.

In order to find out in which chromosome the gene of this cream lies, a second cream female (found February 28 in the same culture as the first) was mated to an eosin black male of the stock which had been made up to test cream II. Two $F_{1}$ pairs (eosin o $\mathrm{x}$ eosin $\sigma^{7}$ ) gave a 9:3:3:1 ratio (table 13), which proves that the gene for this cream is not in the second chromosome.

TABLE 13

The $F_{1}$ and $F_{z}$ offspring from the outcross of a cream III female to an eosin black male

\begin{tabular}{|c|c|c|c|c|c|c|c|}
\hline $1914,3 / 18$ & $\begin{array}{l}\text { WHITE } \\
\text { EOSIN } q\end{array}$ & EOSIN 9 & $\begin{array}{l}\text { YELLOW } \\
\text { WHITE } \sigma^{x}\end{array}$ & Eosin $\sigma^{x}$ & \multicolumn{2}{|c|}{$\begin{array}{l}\text { YELLOW } \\
\text { EOSIN } \text { on }^{\pi}\end{array}$} & whrTe ot \\
\hline 121 & 52 & 61 & 35 & 58 & & & 3 \\
\hline \multicolumn{2}{|c|}{$1914,4 / 4$} & EOSIN & EOSIN BLACE & \multicolumn{2}{|c|}{ CREAM III } & & X CREAM III \\
\hline \multirow{2}{*}{\multicolumn{2}{|c|}{$\begin{array}{l}159 \\
160\end{array}$}} & 118 & 45 & \multirow{2}{*}{\multicolumn{2}{|c|}{$\begin{array}{l}56 \\
41\end{array}$}} & & 15 \\
\hline & & 136 & 49 & & & & 20 \\
\hline & & 254 & 94 & \multicolumn{2}{|c|}{97} & & 35 \\
\hline
\end{tabular}

The fact that this cream is not in chromosome II makes it probable that it is in chromosome III, since chromosome IV is very small. To test this point a cream female from the pure stock made from culture 136 was mated to an eosin ebony male from the stock which had been used in testing cream II. Three pairs of eosin $\mathrm{F}_{1}$ flies gave the approximation to a $2: 1: 1: 0$ ratio observed in table 14 .

The absence of the double recessive cream ebony proved that this cream was in chromosome III, and it was accordingly called cream III; the Roman III being the symbol for the third chromosome.

It was decided to find approximately the locus of cream III in the third chromosome. To do this it was necessary to find 
the amount of crossing over between cream III and some two other genes whose loci were already known. The best method of finding the amount of crossing over is by the backcross, which consists in testing a multiple heterozygote by the corresponding multiple recessive. The double recessive cream ebony III was made up by breeding the eosin ebony and the cream III flies of $\mathrm{F}_{2}$ (culture 361) to each other. Nearly all of these matings gave only eosin flies in $F_{1}$, but one pair gave half of the flies eosin and the other half eosin ebony. These eosin ebony flies were heterozygous for the cream gene since their father was homozygous cream. When these $\mathrm{F}_{3}$ eosin ebony. flies were bred together a quarter of their offspring $\left(\mathrm{F}_{4}\right)$ were cream III ebony. One of

TABLE 14

The $F_{2}$ offspring from the outcross of a cream III female to an eosin ebony male

\begin{tabular}{|c|c|c|c|c|c|c|c|c|}
\hline \multirow{2}{*}{$1914,8 / 3$} & \multicolumn{2}{|c|}{ EOSIN } & \multicolumn{2}{|c|}{ EOSIN } & \multicolumn{2}{|c|}{ CREAM III } & \multicolumn{2}{|c|}{ CREAM III EBONY } \\
\hline & 9 & $\sigma^{9}$ & ᄋ & $0^{7}$ & q & $\sigma^{\pi}$ & $q$ & $\sigma^{7}$ \\
\hline 361 & 43 & 42 & 24 & 23 & 27 & 18 & 0 & 0 \\
\hline 363 & 56 & 50 & 19 & 23 & 16 & 23 & 0 & 0 \\
\hline 371 & 59 & 57 & 19 & 22 & 42 & 26 & 0 & 0 \\
\hline \multirow{2}{*}{ Total.. } & 158 & 149 & 62 & 68 & 86 & 67 & 0 & 0 \\
\hline & \multicolumn{2}{|c|}{307} & \multicolumn{2}{|c|}{130} & \multicolumn{2}{|c|}{153} & \multicolumn{2}{|c|}{0} \\
\hline
\end{tabular}

the resulting cream III ebony males was outcrossed to an eosin female and their $F_{1}$ eosin daughters were backcrossed to fresh cream III ebony males from the general stock which had meanwhile been made up and carried on (table 15).

As soon as this experiment began to produce results, a great variation in the amount of crossing over in the various cultures was noticed. The ebony stock used throughout this experiment was supposed from previous tests (Sturtevant, '13) to be homozygous for a modification of the amount of crossing over in the third chromosome. This modifier $\left(\mathrm{C}_{\mathrm{III}}\right)$ when in the heterozygous form, greatly reduces the amount of crossing over, and it was this kind of result that was expected. Cultures 580 and 582 of table 15 gave a low percentage of crossing over, and in the 
light of subsequent experiments these are known to be the cultures in which the mother was heterozygous for the crossover variation $\left(\mathrm{C}_{\mathrm{mII}} c_{\mathrm{mI}}\right)$. The other three cultures $(578,579,581)$, however, gave a much higher percentage of crossing over, and for this one of two explanations seemed possible. Either the cream III ebony stock was not pure for $\mathrm{C}_{\mathrm{II}}$ as supposed, in which case this high value would be comparable with the regular values obtained in experiments free from $\mathrm{C}_{\mathrm{m}}$; or the eosin stock used as $P_{1}$ (in the mating of cream III ebony male by eosin female) itself carried $\mathrm{C}_{\mathrm{rm}}$ (in heterozygous form, since she gave a ratio of $1: 1$ ), in which case the high crossover value is comparable with the crossover values obtained from mothers homo-

TABIE 15

The coupling backcross offspring from the $P_{1}$ mating of an cream III ebony male to an eosin female. The $F_{1}$ eosin females back-crossed singly to cream $I I I$ ebony males

\begin{tabular}{c|c|c||c|c|c}
\hline $1914,10 / 6$ & $\begin{array}{c}\text { CREAM III } \\
\text { EBONY }\end{array}$ & (EOBIN) & CREAM III & (EOBIN) EBONY & $\begin{array}{c}\text { PER CRNT } \\
\text { CROSSING OVER }\end{array}$ \\
\cline { 2 - 6 } & 74 & 72 & 64 & 78 & 49.3 \\
579 & 55 & 58 & 28 & 24 & 31.5 \\
580 & 107 & 113 & 21 & 15 & 14.1 \\
581 & 73 & 55 & 34 & 45 & 38.1 \\
582 & 87 & 73 & 11 & 9 & 11.1 \\
\hline
\end{tabular}

zygous for $\mathrm{C}$. While crossing over in females heterozygous for $\mathrm{C}_{n \mathrm{~m}}$ is very much lower than in females free from $\mathrm{C}_{\mathrm{m}}$, yet in females homozygous for $\mathrm{C}_{\mathrm{mr}}$ it is the highest of all (Muller, '16). I was not able to decide without testing whether the high values were due to homozygous $\mathrm{C}_{\mathrm{rII}}$ on the one hand or to homozygous not- $\mathrm{C}_{\mathrm{m}}$ on the other.

This question was not tested until December, 1915. Meanwhile the number of stocks of primary mutations had increased to such an extent that it had become necessary to eliminate as many as possible of those stocks which were decreed less generally useful. Among those discarded (or lost) at various times were cream a, cream II; whiting, and cream III. However, the stock of cream III ebony had been spared for this special test. 
In order to see if the experiment would still give the two kinds of results observed before, several $P_{1}$ matings (cream III ebony $o^{7} \times$ eosin $\&$ ) were made, and each father was saved and remated to one of his daughters. Of six such tests five gave the low value and one the high (table 16). The low values corresponded to the expected result that the $F_{1}$ females should be heterozygous for $\mathrm{C}_{\mathrm{nu}}$.

TABLE 16

The B.C. offspring of cream III ebony males outcrossed to eosin females (pairs) and then remated each to a single daughter

\begin{tabular}{|c|c|c|c|c|c|c|}
\hline $1916,1 / 8$ & $\underset{\text { EBONY }}{\text { CREAM III }}$ & EOSIN & CREAM III & $\begin{array}{l}\text { EOSIN } \\
\text { EBONY }\end{array}$ & TOTAL & CROSBOVER \\
\hline $2773\left\{\begin{array}{l}q \ldots \\
0 \ldots\end{array}\right.$ & $\begin{array}{l}58 \\
44\end{array}$ & $\begin{array}{l}52 \\
64\end{array}$ & $\begin{array}{l}8 \\
9\end{array}$ & $\begin{array}{l}7 \\
2\end{array}$ & $\begin{array}{l}125 \\
119\end{array}$ & $\begin{array}{c}\text { per cent } \\
10.6\end{array}$ \\
\hline $2774\left\{\begin{array}{l}q . \\
0^{7}\end{array}\right.$ & $\begin{array}{l}87 \\
45\end{array}$ & $\begin{array}{l}87 \\
36\end{array}$ & $\begin{array}{r}19 \\
8\end{array}$ & $\begin{array}{l}9 \\
8\end{array}$ & $\begin{array}{c}202 \\
97^{1}\end{array}$ & 14.6 \\
\hline $2775\left\{\begin{array}{l}Q . \\
0^{7}\end{array}\right.$ & $\begin{array}{l}47 \\
36\end{array}$ & $\begin{array}{l}55 \\
26\end{array}$ & $\begin{array}{l}6 \\
9\end{array}$ & $\begin{array}{l}7 \\
4\end{array}$ & $\begin{array}{r}115 \\
75\end{array}$ & 13.7 \\
\hline $2776\left\{\begin{array}{l}q \ldots \\
0^{7} . .\end{array}\right.$ & $\begin{array}{l}56 \\
31\end{array}$ & $\begin{array}{l}71 \\
33\end{array}$ & $\begin{array}{r}23 \\
8\end{array}$ & $\begin{array}{l}8 \\
3\end{array}$ & $\begin{array}{c}158 \\
75^{1}\end{array}$ & 18.0 \\
\hline $2777\left\{\begin{array}{l}q . \\
0^{3}\end{array}\right.$ & $\begin{array}{l}33 \\
35\end{array}$ & $\begin{array}{l}34 \\
33\end{array}$ & $\begin{array}{l}22 \\
24\end{array}$ & $\begin{array}{l}24 \\
24\end{array}$ & $\begin{array}{l}113 \\
116\end{array}$ & 41.0 \\
\hline $2778\left\{\begin{array}{c}q \ldots \\
0^{7} \ldots\end{array}\right.$ & $\begin{array}{l}68 \\
52\end{array}$ & $\begin{array}{l}76 \\
63\end{array}$ & $\begin{array}{l}16 \\
10\end{array}$ & $\begin{array}{r}6 \\
15\end{array}$ & $\begin{array}{l}166 \\
140^{2}\end{array}$ & 15.3 \\
\hline
\end{tabular}

1 The two cultures 2774 and 2776 produced only half as many sons as daughters owning to the occurrence of a lethal (lethal 11), the mutation for which must have taken place in the eosin stock some time before.

' Culture 2778 gave rise to a mutant 'roof wings' which likewise had originated in the eosin stock.

That backcrosses made up from the low crossover cultures continued to give only low values is shown by table 17 . The occurrence of a high value among such cultures would have been an indication that one of the cream III ebony males previously used had failed to be homozygous for $\mathrm{C}_{\mathrm{rr}}$. 
If the high value of culture 2777 were not due to a homozygous not- $\mathrm{C}_{\mathrm{nI}}$ condition, then it should be due to the converse causehomozygosity for $\mathrm{C}_{\mathrm{II}}$; that is, the eosin stock which had furnished the other parent for our original experiment had itself been carrying the linkage variation $\mathrm{C}_{\mathrm{III}}$. In this case every cream III ebony fly from the high-value culture should be homozygous for $\mathrm{C}_{\mathrm{III}}$, and should give, when outcrossed to eosin flies free from $\mathrm{C}_{\mathrm{III}}$, all offspring heterozygous for $\mathrm{C}_{\mathrm{mI}}$ and all daughters

TABLF 17

The B.C. $\left(F_{3}\right)$ offspring given by continued breeding from a low crossover value line (2773) of table 16

\begin{tabular}{|c|c|c|c|c|c|c|}
\hline $1916,2 / 1$ & $\underset{\text { EBONY }}{\text { CREAM III }}$ & $\operatorname{cosin}$ & CREAM IXI & $\underset{\text { EBONY }}{\text { DOSIN }}$ & TOTAI & $\begin{array}{c}\text { CROSSOVER } \\
\text { VALUESS }\end{array}$ \\
\hline $3124\left\{\begin{array}{l}q \ldots . \\
\sigma^{7} \ldots\end{array}\right.$ & $\begin{array}{l}60 \\
67\end{array}$ & $\begin{array}{l}50 \\
62\end{array}$ & $\begin{array}{l}5 \\
3\end{array}$ & $\begin{array}{r}8 \\
11\end{array}$ & 266 & 10.1 \\
\hline $3402\left\{\begin{array}{l}9 . . . \\
\sigma^{7} \ldots\end{array}\right.$ & $\begin{array}{l}43 \\
28\end{array}$ & $\begin{array}{l}61 \\
52\end{array}$ & $\begin{array}{l}10 \\
10\end{array}$ & $\begin{array}{r}7 \\
10\end{array}$ & 221 & 16.7 \\
\hline $3403\left\{\begin{array}{l}\text { …... } \\
\sigma^{7} \ldots\end{array}\right.$ & $\begin{array}{l}32 \\
41\end{array}$ & $\begin{array}{l}55 \\
61\end{array}$ & $\begin{array}{l}12 \\
10\end{array}$ & $\begin{array}{l}7 \\
5\end{array}$ & 223 & 15.2 \\
\hline $3404\left\{\begin{array}{l}9 . . . \\
0^{7} \ldots .\end{array}\right.$ & $\begin{array}{l}18 \\
20\end{array}$ & $\begin{array}{l}23 \\
30\end{array}$ & $\begin{array}{l}3 \\
6\end{array}$ & $\begin{array}{l}3 \\
5\end{array}$ & 108 & 15.7 \\
\hline $3742\left\{\begin{array}{l}9 . . \\
7 . .\end{array}\right.$ & $\begin{array}{l}30 \\
39\end{array}$ & $\begin{array}{l}65 \\
50\end{array}$ & $\begin{array}{l}16 \\
12\end{array}$ & $\begin{array}{l}6 \\
7\end{array}$ & 225 & 13.8 \\
\hline $3743\left\{\begin{array}{l}0 . . . \\
\sigma^{7} \ldots .\end{array}\right.$ & $\begin{array}{l}23 \\
16\end{array}$ & $\begin{array}{l}39 \\
33\end{array}$ & $\begin{array}{l}7 \\
5\end{array}$ & $\begin{array}{l}2 \\
4\end{array}$ & 129 & 14.0 \\
\hline Total. & 417 & 581 & 99 & 75 & 1172 & 14.8 \\
\hline
\end{tabular}

giving the low value. One such test was made and the daughters all showed the low value (table 18).

Both of these tests (tables 17 and 18) pointed to the presence of $\mathrm{C}_{\text {II }}$ in the particular eosin stock used to outcross to, though they were not conclusive because of being done on so small a scale. Conclusive proof (in press, Carnegie Publication no. 287) was soon furnished by Sturtevant, who had been trying for some time to get, by crossing over a stock, which should be $\mathrm{C}_{\mathrm{mI}}$ but not 
ebony. He made tests of the eosin stock, and found some individuals that carried $\mathrm{C}_{\mathrm{rm}}$, from which he secured the desired stock.

In making the tests of the last experiment (table 18) the outcrosses of cream III were made to eosin dichaete in order to establish by a three-point linkage experiment the location of cream III in the third chromosome. The preceding experiments (tables 15, 16, and 17) had already given 404 crossovers in a total of 2887 flies, or 14 per cent, in cases where the mothers were heterozygous for $\mathrm{C}_{\mathrm{II}}$. In other experiments (by Sturtevant and Muller) in which ebony has been run with various third chromo-

TABLE 18

The B. C. offspring from the outcross of a cream III ebony female from ary7 to an eosin dichaete male, and the $F_{1}$ eosin dichaete females backcrossed singly to cream III ebony males

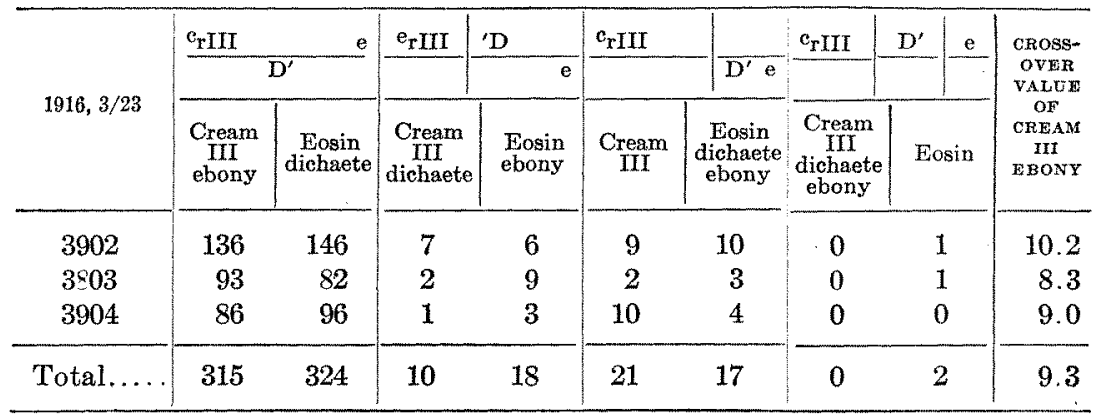

some genes in heterozygous $\mathrm{C}_{\mathrm{Ir}}$ condition, the amount of crossing over of sepia with ebony has been $25 \pm$, of pink with ebony 2 and of ebony and rough $0.0+$. That is, there is some crossing over in the region to the left of ebony, nearly all of which is in the sepia pink region, but almost none to the right of ebony (ebony rough $0.0+$ ). It seemed probable from the crossover value 14.0 that cream III lies to the left (i.e., near the sepia end). and at a position between sepia and pink. A comparison of the high value for cream III ebony (41.0) with the known homozygous $\mathrm{C}_{\mathrm{xI}}$ values (Muller) for sepia ebony $(48+)$ and for pink ebony $(46+)$ led to this same conclusion though less definitely. The mutant dichaete was well adapted for this test because of 
its dominance, its known position in the suspected region, and from its easy classification in the same flies with cream III, it being a wing and bristle character. The double crossover result (table 19) showed that cream III is situated to the left of dichaete. The cream III dichaete crossover value (4.2) is considerably smaller than the sepia dichaete crossover value (14.8) found in heterozygous $\mathrm{C}_{\mathrm{III}}$ experiments, so that cream III is known to be between sepia and dichaete. The normal amount of crossing over between sepia and dichaete is 11.0 so that the probable position of cream III is 3.1 to the left of dichaete or 7.9 to the right of sepia which is the zero position.

TABLE 10

The B.C.offspring from the outcross of a cream III ebony female to a dichaete male, and the $F_{1}$ dichaete females backcrassed singly to cream III ebony males

\begin{tabular}{|c|c|c|c|c|c|c|c|c|c|c|c|c|c|c|c|c|}
\hline \multirow[b]{2}{*}{$\begin{array}{l}1916 \\
8 / 22\end{array}$} & \multicolumn{8}{|c|}{ RED } & \multicolumn{8}{|c|}{ EOSIN } \\
\hline & $\begin{array}{c}c_{r I I I} \\
e\end{array}$ & $D^{\prime}$ & $c_{\mathrm{rIII}}$ & $\mathrm{e}$ & $c_{\mathrm{rIII}}$ & $\begin{array}{l}D^{\prime} \\
\mathrm{e}\end{array}$ & $\mid \begin{array}{c}c_{\mathrm{rIII}} \\
\mathrm{D}^{\prime} \\
\mathrm{e}\end{array}$ & & $\begin{array}{l}\mathrm{e}_{\mathrm{rII}} \\
\mathrm{e}\end{array}$ & $D^{\prime}$ & $\begin{array}{c}c_{r I X I} \\
D^{\prime}\end{array}$ & $\mathrm{e}$ & $\mid c_{\mathrm{rIII}}$ & $\begin{array}{c}D^{\prime} \\
\mathrm{e} \\
\end{array}$ & $\mid \begin{array}{c}\mathrm{c}_{\mathrm{rII}} \\
\mathrm{D}^{\prime} \\
\mathrm{e}\end{array}$ & \\
\hline 4990 & 24 & 23 & 1 & 7 & 0 & 0 & 0 & 0 & 9 & 13 & 1 & 1 & 1 & 2 & 0 & 0 \\
\hline 4991 & 35 & 38 & 1 & 8 & 3 & 2 & 0 & 0 & 33 & 32 & 0 & 0 & 1 & 2 & 1 & 0 \\
\hline 4996 & 5 & 4 & 0 & 1 & 0 & 3 & 0 & 0 & 20 & 10 & 0 & 0 & 1 & 3 & 0 & 0 \\
\hline 4997 & 9 & 13 & 1 & 2 & 3 & 0 & 0 & 0 & 11 & 17 & 0 & 0 & 0 & 0 & 0 & 0 \\
\hline 4998 & 50 & 47 & 0 & 8 & 1 & 2 & 0 & 0 & 45 & 58 & 2 & 3 & 0 & 2 & 0 & 0 \\
\hline tal. & 123 & & 3 & 26 & 7 & 7 & 0 & 0 & 118 & 130 & 3 & 4 & 3 & 9 & 1 & 0 \\
\hline
\end{tabular}

The occurrence of the linkage variation and its testing had diverted me from making tests of the effect of the cream III gene in the absence of eosin as a base. Accordingly, the preceding experiment was repeated, but in such a fashion that half of the flies should be not-eosin. A cream III ebony female from the high value stock was outcrossed to a simple dichaete male. Several of the dichaete daughters $\left(\frac{c_{\mathrm{rrII}}+\mathrm{e}_{\mathrm{xrr}}}{+\mathrm{D}^{\prime}++}\right)$ were back crossed singly to cream III ebony males of the high stock. The result (table 19, left side) showed that the gene responsible for the dilution of eosin to the cream color gave by itself a color somewhat similar to purple, that is, a 'magenta.' But when 
separations were attempted it was found that this color was not sufficiently distinct from the red to make classification accurate. In the eosin half of the flies on the other hand, the separation was easy and entirely accurate. That is, while the so-called 'cream III' gene by itself gave a certain effect, it gave so much more marked an effect in the presence of eosin that it was decided to retain the name 'cream III' instead of renaming the mutant 'magenta.' The separations in the not-eosin half of table 19 correspond roughly to those of the eosin half, but the large size of the ebony not-magenta class is due to the impossibility of distinguishing the 'magenta' character, even though it was undoubtedly present in most of these twenty-six flies. If this character were accurately classifiable (as magenta) without first laboriously combining eosin with all the flies used in the matings of each experiment, it would be incomparably more useful even if slightly less interesting from our present viewpoint. However, an experiment planned through eight generations had to be abandoned because it was found impractical to distinguish between the cream III and the not-cream III where eosin was not present as a sensitizer. But this aborted experiment revealed that the ebony was a disturbing factor-that in the not-ebony flies the distinction was sharper than in ebony flies. The new possibility arose that the mutation could be used (as magenta) by excluding ebony from all the experiments. While this has not been adequately tested, it seems hopeful that with experience one may be able to use this eye-color without a preliminary eosinization of all the stocks, though it is not to be denied that in the presence of eosin the ease and speed of classification would be greater.

\section{CREAM B}

An eosin female from a stock of non-disjunction when mated to a bar male gave (culture 82, March 10, 1914) among the eosin sons one whose eye color was as light as that of cream II or cream III. This male was outcrossed to a wild female and in $\mathrm{F}_{2}$ gave creams among the eosin sons, but no disturbance of the color of the not-eosin flies (cultures 183, 184, 185). The 
$\mathrm{F}_{2}$ ratio was again $12: 3: 1$, as in similar crosses with other recessive specific dilutors. But the creams (cream b) which occurred in this $\mathrm{F}_{2}$ were not as pale as any of the preceding creams.

From the circumstances of the appearance of cream $b$-that it was observed in the $F_{1}$ of an outeross and as a single individual - we should expect it to be a dominant, but as a matter of fact it proved to be a recessive. It seems probable, in explanation, that more creams were actually present in this $F_{1}$ but were overlooked, since attention was distracted by the simultaneous appearance in the same culture of still another mutation (lethal 4), and more especially since the effect of cream $b$ is rather slight. Only occasionally was one of the $F_{2}$ creams as marked as the grandfather, and the mutation might not have been recognized at all were it not that an extreme fluctuant had attracted attention. Since cream b is recessive, we must suppose that the gene was present in both parent stocks. It could have been present in the bar stock and been undetected because of the lack of eosin, without which it has no visible effect. And the character might readily have been present in the eosin non-disjunction stock and have been passed over as an age variation, since as we ordinarily see flies from a stock culture they are of all ages and of corresponding densities of pigmentation.

A pure breeding stock of cream $b$ was made up for use in back crossing. By this time we were in possession of a good second chromosome dominant 'star' and likewise of a perfect third chromosome dominant 'dichaete,' which mutants have now become the most important in their respective chromosomes. By aid of these two dominants it is very easy to determine in a single experiment whether a given mutant is in the second or third chromosome. Thus, in the case of cream b, a stock of eosin star dichaete was made up and used in making a $P_{1}$ cross to the cream. Then $F_{1}$ eosin males which showed both star and dichaete and which were heterozygous for the recessive cream were backcrossed to cream $b$ females of stock. There is no crossing over in the male of Drosophila, so that if cream b were in the second chromosome, none of the B.C. (back cross) stars should be cream, while half of the dichaete should be cream and half 
TABLE 20

The $B . C$. offspring from the $P_{1}$ mating of an eosin star dichaete male to a cream $b$ female and the backcrossing of the $F_{1}$ eosin star dichaete male to cream $b$

females

\begin{tabular}{|c|c|c|c|c|c|c|c|c|c|}
\hline \multirow{2}{*}{\multicolumn{2}{|c|}{$1916,9 / 8$}} & \multicolumn{4}{|c|}{ NON-CROSSOVIRS } & \multicolumn{4}{|c|}{ CROSSOVERS (IN MALE) } \\
\hline & & $\begin{array}{c}\text { Eosin } \\
\text { star }\end{array}$ & $\begin{array}{c}\text { Eosin } \\
\text { star } \\
\text { dichaete }\end{array}$ & Cream b & $\begin{array}{l}\text { Cream b } \\
\text { dichaete }\end{array}$ & $\underset{\text { cream b }}{\text { Star }}$ & $\begin{array}{c}\text { Star } \\
\text { cream b } \\
\text { dichaete }\end{array}$ & Eosin & $\begin{array}{c}\text { Eosin } \\
\text { dichaete }\end{array}$ \\
\hline \multirow{2}{*}{5155} & q & 20 & 25 & 26 & 12 & 0 & 0 & 0 & 0 \\
\hline & $\sigma^{\pi} \ldots$ & 19 & 21 & 21 & 26 & 0 & 0 & 0 & 0 \\
\hline \multirow{2}{*}{5409} & $\int 0$ & 14 & 21 & 18 & 26 & 0 & 0 & 0 & 0 \\
\hline & 107 & 14 & 15 & 17 & 24 & 0 & 0 & 0 & 0 \\
\hline \multicolumn{2}{|c|}{ Total.......... } & 67 & 82 & 82 & 77 & 0 & 0 & 0 & 0 \\
\hline
\end{tabular}

not. If, on the, other hand, the cream were in the third chromosome, then none of the B.C. dichaetes should be cream, while the star and cream should assort at random. The experiment proved that the gene for cream $b$ is in the second chromosome (table 20).

An (eosin) star female and a cream b male selected from the B.C. offspring gave in the next generation the amount of crossing over between star and cream b (table 21). This value of 22.1 includes some double crossing over, and the corrected or 'map' distance is probably about 22.5. The chances are in favor of the cream $b$ locus being to the right of star, since star happens to occupy the leftmost of the known loci.

TABLE 21

The $B$. C. offspring given in $F_{3}$ by an eosin star female and a cream $b$ male from table 20

\begin{tabular}{|c|c|c|c|c|}
\hline \multirow{2}{*}{$1914,10 / 20$} & \multicolumn{2}{|c|}{ NON-OROSSOVERS } & \multicolumn{2}{|c|}{ CROSSOVERS (IN FEMALE) } \\
\hline & Eosin star & Cream b & Star cream b & Eosin \\
\hline $5593\left\{\begin{array}{l}q \ldots \ldots \\
\sigma^{7} \ldots \ldots\end{array}\right.$ & $\begin{array}{l}36 \\
22\end{array}$ & $\begin{array}{l}41 \\
41\end{array}$ & $\begin{array}{r}8 \\
12\end{array}$ & $\begin{array}{r}8 \\
12\end{array}$ \\
\hline $5824\left\{\begin{array}{l}q \ldots \ldots \\
0^{x} \ldots \ldots\end{array}\right.$ & $\begin{array}{l}47 \\
28\end{array}$ & $\begin{array}{l}39 \\
49\end{array}$ & $\begin{array}{l}13 \\
11\end{array}$ & $\begin{array}{r}7 \\
15\end{array}$ \\
\hline Total......... & 133 & 170 & 44 & 42 \\
\hline
\end{tabular}




\section{PINKISH}

In the fall of 1913 a stock of eosin black had been made up with which to test the chromosome group of cream II. In the following summer (July 27, 1914) I noticed that a few of the males were somewhat lighter in eye color than the others, but seemed chiefly noticeable because of the weakness of the yellow component of the eosin eye color. The color of the regular eosin male is a pinkish yellow; the color of creams a, II, III, and $b$ is nearly a pure yellow with little of the pinkish tinge, while this new color was somewhat the converse of this and was pale pink with relatively little yellow.

One of these males mated to a sister gave all of the sons of this pinkish color and all the daughters of a similar color, which is, however, much harder to distinguish from standard eosin. It seems that this character is somewhat sex-limited in the same direction as eosin. Pure stock of the mutation had been obtained at once through the happy selection of a pure pinkish female which had been taken to be simply an eosin female of somewhat lighter eye color because of being freshly hatched.

Since pinkish appeared in a stock of eosin black, material was on hand to test the chromosome group at once. Accordingly, black pinkish females were outcrossed to eosin males and the $F_{1}$ eosin females, standard eosin in color, were backerossed to black pinkish males. In the B.C. cultures half of the flies were notblack, and the not-black pinkish flies were seen to be less markedly 'pinkish' in tone than the blacks. In the absence of black the eye color was more nearly like that of the other creams, though the amount of dilution is less than in the case of any of the other creams. In the first of these B.C. cultures (table 22) males and females were both classified together. Some question having been raised as to the accuracy of the separation of pinkish from eosin among females, the cross was repeated, and the more readily classifiable males (last three cultures) gave the same result as before. It was seen that the new or crossover combinations were as numerous (51.4 per cent) as the original classes, and this independent inheritance was taken to mean that the 
gene for pinkish is not in the second chromosome. While this was a mistaken notion-the true relation being that the gene is so far away from black that in the female there is entirely free crossing over-yet it led to the device of the efficient 'double mating' method of ridding a given stock of an undesired recessive.

If pinkish were in the third chromosome, then the presence of the black in the pinkish stock could be of no advantage, and might be a very serious handicap, since it would prevent the use of all our third chromosome stocks containing ebony or sooty. The first step in the elimination of black was to mate together some of the not-black pinkish flies of table 22. One-third of the not-black offspring of such pairs should be of the desired

TABLE 22

The offspring given by the $F_{1}$ eosin-eyed daughters from the outcross of black pinkish females to eosin males, when back-crossed to black pinkish males

\begin{tabular}{c|c|c|c|c}
\hline \multirow{2}{*}{$1914,9 / 23$} & \multicolumn{2}{|c|}{ NoN-crossovers } & \multicolumn{2}{|c}{ crossovers } \\
\cline { 2 - 4 } & Black pinkish & (Eosin) & (Eosin) black & Pinkish \\
\hline 525 & 70 & 81 & 71 & 84 \\
526 & 36 & 29 & 32 & 22 \\
2424 & 25 & 21 & 24 & 35 \\
2425 & 24 & 27 & 29 & 31 \\
2426 & 28 & 24 & 14 & 29 \\
\hline Total........ & 183 & 182 & 170 & 201 \\
\hline
\end{tabular}

kind, that is, entirely free from black. Our task was then to pick out from the mixture of pure grays and grays heterozygous for black some pure gray males for outcrossing to eosin females. In this special case we were aided by the fact that black happens to be slightly dominant, that is, the heterozygous blacks are somewhat darker than the pure grays. While this difference is not marked enough to be used regularly in classification, yet it enables us to pick out by inspection a greater proportion of pure grays than we would get by random selection. Four such males were selected as being probably free from black and were mated to eosin females. Into the same bottle with each pair of these flies was put a virgin (red-eyed) black female. The offspring from these two mothers are easily distinguished, since 
they are eosin-eyed if from the eosin mother and red-eyed if from the black mother. The offspring from the black mother constitute a test of whether the father were free from black, for in this case none of the red-eyed offspring hatching in the double mating culture should be black, while if the father were heterozygous for black half of the red-eyed offspring should be black. Only one of the four cultures gave black offspring, and this culture was then discarded. The eosin-eyed flies of the other three cultures were all heterozygous for pinkish and at the same time free from black. By mating together some of these eosineyed flies pure pinkish offspring should be obtained as a quarter of the offspring. A more efficient method, and the one actually followed, was to save the fathers and mate them to their eosineyed daughters, since in this case half, rather than a quarter, of the progeny should be pure pinkish.

In order to show by an actual test that the gene for pinkish is in the third chromosome, it was decided to take advantage of the fact of no crossing over in the male and to run a back-cross test of a male heterozygous for pinkish and for the dominant third-chromosome character dichaete. It was now realized that the back-cross tests of females heterozygous for pinkish and black had not excluded the possibility of pinkish being in the second chromosome, though they had shown that, if so, it could be only in one or the other end-region and not near black. Accordingly, exactly the same procedure was followed as in the tests for the location of cream $b$, that is, a pinkish female was outcrossed to a male which had the dominant second-chromosome star as well as dichaete. The $F_{1}$ eosin star dichaete males were then back-crossed to pinkish females. The result showed (table 23) that the gene for pinkish is in the second and not the third chromosome; for, as well as could be judged, none of the star flies were pinkish, while all the not-stars seemed to be pinkish, and dichaete was present in half of both the star and the pinkish classes.

In the light of this test, and from the fact that there was about 50 per cent of crossing over between black and pinkish, we could place pinkish in either the extreme left or the extreme right end- 
TABLE 23

The B. C.offspring given by $F_{1}$ eosin star dichaete sons, from the outcross of a pinkish female to a star dichaete male, when back-crossed to pinkish females

\begin{tabular}{|c|c|c|c|c|c|c|c|c|c|}
\hline \multirow{2}{*}{\multicolumn{2}{|c|}{$1916,8 / 25$}} & \multicolumn{4}{|c|}{ NON-CROSSOVERS } & \multicolumn{4}{|c|}{ CROSSOVERS (IN MALF) } \\
\hline & & $\begin{array}{c}\text { (Eosin) } \\
\text { star }\end{array}$ & $\begin{array}{c}\text { (Eosin) } \\
\text { star } \\
\text { dichaete }\end{array}$ & Pinkish & $\begin{array}{l}\text { Pinkish } \\
\text { dichaete }\end{array}$ & $\underset{\text { pinkish }}{\text { Star }}$ & \begin{tabular}{c|} 
Star \\
pinkish \\
dichaete
\end{tabular} & (Eosin) & $\begin{array}{l}\text { (Eosin) } \\
\text { dichaete }\end{array}$ \\
\hline \multirow{2}{*}{5029} & $\int q$ & 10 & 12 & 10 & 9 & 0 & 0 & 0 & 0 \\
\hline & $\sigma^{7} \ldots$ & 17 & 13 & 16 & 22 & 0 & 0 & 0 & 0 \\
\hline \multirow{2}{*}{5266} & \{ & 22 & 20 & 18 & 21 & 0 & 0 & 0 & 0 \\
\hline & 107. & 20 & 20 & 21 & 26 & 0 & 0 & 0 & 0 \\
\hline \multicolumn{2}{|c|}{ Total. } & 69 & 65 & 65 & 78 & 0 & 0 & 0 & 0 \\
\hline
\end{tabular}

region of the second chromosome. Fortunately, one advantage of the test just described is that it left us in possession of females heterozygous for star and for pinkish, and a back-cross test showed (table 24) that there is very free crossing over between star and pinkish. Pinkish is known, therefore, to be in the right-hand end of the second chromosome in the neighborhood of arc, speck, balloon, etc. Had the test given almost no crossing over between star and pinkish, we should have known that the gene for pinkish was in the left end, but this was not the case.

A test as to whether the pinkish gene would have any visible effect in the absence of eosin showed (table 25) that in a very small per cent of the flies homozygous for pinkish there is a very slight dilution. This dilution is, however, so slight that rarely could one be sure that the effect observed is due to dilution rather than to the slight normal fluctuation of the red.

TABLE 24

The B. C. offspring given by a star female from table $\$ 3$ when back-crossed to a pinkish male

\begin{tabular}{|c|c|c|c|c|}
\hline \multirow{2}{*}{$1916,9 / 23$} & \multicolumn{2}{|c|}{ NON-CROSSOVERS } & \multicolumn{2}{|c|}{ CROSSOYERS } \\
\hline & (Eosin) star & Pinkish & Star pinkish & $(\operatorname{Eosin})$ \\
\hline $5267 \begin{cases}9 & . . . \\
\sigma^{\circ} & \ldots . .\end{cases}$ & $\begin{array}{l}19 \\
26\end{array}$ & $\begin{array}{l}30 \\
26\end{array}$ & $\begin{array}{l}19 \\
19\end{array}$ & $\begin{array}{l}20 \\
16\end{array}$ \\
\hline Total. & 45 & 56 & 38 & 36 \\
\hline
\end{tabular}


TABLE 25

The $F_{2}$ offspring given by the $F_{1}$ wild-type females and $F_{1}$ eosin males, from the outcross of pinkish females to wild males

\begin{tabular}{c|c|c|c|c}
\hline $1916,10 / 28$ & WILD-TYPE & $\begin{array}{c}\text { (NOT-EOSIN) } \\
\text { PINKISI) }\end{array}$ & EOSIN & PINKISH \\
\cline { 2 - 4 } 5678 & 121 & 5 & 76 & 24 \\
5680 & 52 & 2 & 46 & 17 \\
5703 & 63 & 14 & 59 & 18 \\
5704 & 57 & 6 & 52 & 26 \\
5705 & 80 & 3 & 67 & 18 \\
\hline Total......... & 373 & 30 & 300 & 103 \\
\hline
\end{tabular}

CREAM C

While looking over the eosin stock (July 13, 1916) in search of a virgin female, I noticed that a few of the flies seemed to be unusually light in eye color. If this paleness were of genetic origin, then the gene must be of recent mutation, for on two occasions subsequent to the discovery of creams whose origin might be traced back to the eosin stock, this stock had been bred in such a way as to make it extremely unlikely that any cream or other eye-color mutation then present could fail to be eliminated.

A pale eye color due to a mutation within the eosin stock might be an allelomorph of eosin, a specific modifier of eosin, or a non-specific modifier, such as vermilion or pink. The gene for the modifier might be sex-linked or be in any of the other three chromosomes. Only one experiment was carried out with this pale eye color, but this experiment was so planned that it answered all the above points. One of the pale females was mated to a star dichaete male. The $F_{1}$ offspring showed at once that the pale color was due neither to an allelomorph of eosin nor to a sex-linked modifier, for the sons were all standard eosin in eye color. Likewise the color was a strict recessive, both in eosin (the sons) and in red (the daughters).

For the production of $F_{2}, F_{1}$ wild-type females and $F_{1}$ eosin star dichaete males were mated together. The first point observed in $\mathrm{F}_{2}$ was that the gene produced no visible effect by itself, for in that half of the offspring that were not-eosin none of the 
eyes were of other than the normal red of the wild-type. On the other hand, among the eosin-eyed offspring about a quarter were of the light color, and this without noticeable sex limitation, that is, the females and males were diluted to the same proportionate extent. On analyzing the distribution of the cream with respect to the second chromosome dominant star and the third chromosome dominant dichaete, it was seen that the gene for the cream is contained in the second chromosome, for the cream appeared only in the flies that were not star, all the flies being either star or cream and none being both star and cream or neither, which condition is in accord with expectation from the lack of crossing over in the male. The $2: 2: 0: 0$ ratio observed

TABLE 26

The $F_{2}$ offspring given by $F_{1}$ wild-type females and $F_{1}$ eosin star dichaete males from the outcross of a cream c female to a star dichaete male

\begin{tabular}{|c|c|c|c|c|c|c|c|c|c|c|c|c|}
\hline $1916,10 / 20$ & $s^{\prime}$ & $\stackrel{\mathrm{S}^{\prime}}{\mathrm{D}^{\prime}}$ & + & $\mathrm{D}^{\prime}$ & $\frac{w^{e}}{S^{\prime}}$ & $\begin{array}{l}\mathrm{w}^{\mathrm{e}} \\
\mathrm{S}^{\prime} \\
\mathrm{D}^{\prime}\end{array}$ & $\begin{array}{c}\left(\mathrm{w}^{\mathrm{e}}\right) \\
\mathrm{c}_{\mathrm{re}}\end{array}$ & $\begin{array}{c}\left(w^{e}\right) \\
\mathbf{c}_{\mathrm{rc}} \\
\mathrm{D}^{\prime}\end{array}$ & $\mathrm{w}^{\mathrm{e}}$ & $\mathrm{w}^{\mathrm{e}}$ & $\begin{array}{l}\text { (we) } \\
\mathrm{S}^{\prime} \\
c_{\mathrm{rc}}\end{array}$ & $\begin{array}{l}\left(w^{e}\right) \\
S^{\prime} \\
c^{c_{r e}} \\
D^{\prime}\end{array}$ \\
\hline $5588^{1}$ & 26 & 21 & 32 & 23 & 23 & 34 & 11 & 11 & 14 & 15 & 0 & 0 \\
\hline $5631^{1}$ & 40 & 32 & 33 & 34 & 40 & 42 & 18 & 16 & 10 & 8 & 0 & 0 \\
\hline 5654 & 17 & 37 & 32 & 44 & 40 & 43 & 21 & 17 & 21 & 23 & 0 & 0 \\
\hline Total. & 83 & 90 & 97 & 101 & 103 & 119 & 50 & 44 & 45 & 46 & 0 & 0 \\
\hline
\end{tabular}

${ }^{1}$ Culture 5588 and 5631 produced 'apterous'as the result of a fresh mutation which took place in the cream c stock (Metz, Am. Nat., '14, pp. 675-692).

in the case of star and cream $c$ is in sharp contrast to the $1: 1: 1: 1$ ratio in the case of cream $c$ and dichaete in the same experiment. There were as many creams among the dichaetes as among the not-dichaetes, as is expected from the free assortment of genes in different chromosomes.

Up to this point there had been no confusion possible among the various modifiers; for the effects produced had been different in one or more of the following respects: in degree, in color tone, in dominance, in specificity, in interaction with other mutants, in the chromosome concerned, or in the locus within that chromosome. In the case of cream c, there was the chance of confusion, since in tone cream $c$ is not different from cream b, though in 
the amount of dilution (degree) there seems to be a very slight difference. The fact that they are both in the same chromosome (II) made essential a further test of their distinctness. The method of linkage (a comparison of the star cream c value with the star cream b value) would be crucial only in case the values were quite different. An easier method, and one which at the same time disposes of the question of allelomorphism is to make a cross between the two types. When this was done (culture 5721 ) it was found that the $F_{1}$ flies were standard eosin in color, as is expected from the cross of two distinct recessives. Evidently cream $c$ is neither cream b nor an allelomorph of cream $b$, and this is the only case where confusion was possible.

\section{SUMMARY}

The significant facts with respect to the origin and the inheritance of these modifiers are summarized in table 27 in which the primary arrangement is according to the order in which the modifiers were discovered. The first four modifiers appeared in rapid succession in the summer and fall of 1913 and were worked out almost simultaneously. In 1914 three more were found,

TABLE 27

Summary of the origin and inheritance of the specifie modifiers of cosin

\begin{tabular}{|c|c|c|c|c|c|c|c|c|}
\hline \multirow{2}{*}{ MUTANT } & \multirow{2}{*}{ 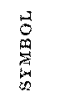 } & \multicolumn{5}{|c|}{ ORIGIN } & \multirow{2}{*}{ 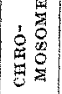 } & \multirow{2}{*}{ Locus } \\
\hline & & Finder & Date & Stook & Type & Culture & & \\
\hline Cream a. & $c_{\text {ra }}$ & Bridges & $1913,7 / 15$ & $\begin{array}{l}\text { Non-disjunc- } \\
\text { tion }\end{array}$ & $w$ or $w^{e}$ & n 43 & - & - \\
\hline Cream II. & $c_{\mathrm{rII}}$ & Bridges & $1913,9 / 15$ & Lethal 2 & W & - & II & - \\
\hline Dark.... & - & Bridges & $1913,9 / 23$ & $\begin{array}{c}\text { Non-disjunc- } \\
\text { tion experi- } \\
\text { ments }\end{array}$ & $\mathrm{w}$ or $\mathrm{w}^{\theta}$ & n 100 & - & 一 \\
\hline Whiting... & - & Bridges & $1913,11 / 21$ & $\begin{array}{c}\text { Non-disjunc- } \\
\text { tion experi- } \\
\text { ments }\end{array}$ & w or $w^{e}$ & M67 & - & - \\
\hline Cream III. & $c_{\mathrm{n} X \mathrm{X}}$ & Wallace & $1914,2 / 27$ & Lethal 1a & $W$ or $w^{e}$ & 一 & III & 7.9 \\
\hline Cream b.. & $\mathrm{c}_{\mathrm{rb}}$ & Bridges & $1914,3 / 10$ & $\begin{array}{c}\text { Non-disjunc- } \\
\text { tion experi- } \\
\text { ments }\end{array}$ & $W$ and $w^{e}$ & 82 & II & 22.5 \\
\hline Pinkish... & - & Bridges & $1914,7 / 27$ & Eosin & $w^{e}$ & - & II & $106=$ \\
\hline Cream c.. & $c_{\mathrm{ro}}$ & Bridges & $1916,7 / 21$ & Eosin & $w^{e}$ & - & II & - \\
\hline
\end{tabular}


and another in 1916. On various other occasions dilute eosins have been observed whose inheritance has not been followed in detail. $^{7}$

Origin of modifiers. All of the modifiers were first detected in stocks or experiments involving eosin. This fact is not the result of any influence of eosin upon mutation, but has a simple explanation in the fact that the modifiers produce little or no visible effect except when brought into coaction with eosin, and hence they pass undetected no matter how numerous, or what their origin, until this condition is satisfied. Only the last two modifiers, 'pinkish' and 'cream c,' were found in stocks pure for eosin, and.in these cases the mutation might have occurred previously and have been incorporated with the eosin stock. The other six modifiers were found in experimental cultures in which only half of the flies were eosin; and in these cases it is usually not possible to say whether the modifier originated in or was introduced through the eosin or the not-eosin half of the experiment. In the case of cream II, there is good evidence that the mutation had occurred in a wild stock and had lurked there undetected until the cross to eosin brought it out of hiding. Cream $b$ seems to have been present in both parent stocks. Creams a and II, dark and whiting, may have arisen in either, though the probability is on the side of the not-eosin parent, since these modifications were likely to have been detected if present in the eosin parent stocks.

The scale of modifications. A graphic representation and comparison of the color differences produced by the modifiers is. given in diagram 1.

In constructing this diagram two standards were chosen, namely, the colorless eye produced by the interaction of eosin and 'whiting', and the unmodified eosin. The modified eosins were then spaced along the line connecting these grades in proportion to their intensities of color. That is, homozygous cream II is the lightest of the other modifications and 'dark' is the darkest. Pinkish is the weakest of the dilutors of eosin. Creams

\footnotetext{
${ }^{7}$ In 1918 two other creams have been found, and the inheritance of one of these presents features of exceptional interest for the chromosome theory of heredity.
} 
$\mathrm{c}, \mathrm{b}$, and a are quite similar in color, $\mathrm{b}$ and $\mathrm{c}$ being especially alike. Cream III is about half-way in color between eosin and white. The grades represent, as near as could be approximated, the mode of each color modification; there is in each case some fluctuation in the direction away from the eosin grade and a greater range in the direction toward eosin. Since the eosin

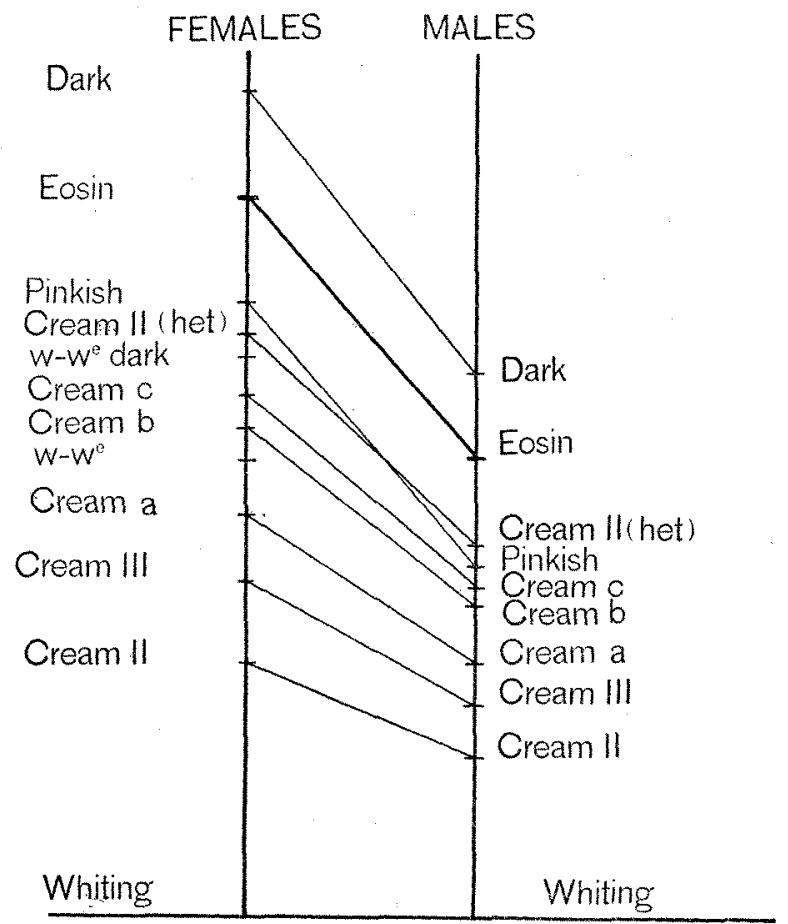

Diagram 1. The scale of modifications of eosin in females and males (modal grades).

male is of a lighter eye color than the eosin female, it became necessary to arrange two such series of grades in order to represent the total range. After the separate distributions of color for the female and the male had been plotted, lines were drawn connecting the corresponding types in the male and female series. The surprising fact was then observed that all but one of the lines, if continued, would intersect the base line at about the 
same point. This was a striking revelation of a relationship vaguely realized before - that the modification by each of these genes is proportionately as great in the male as in the female, although the actual modification is much greater in the case of the female.

Sex limitation. The above relation does not hold in the case of pinkish, for the connecting line cuts the base line at a point only about three fourths as distant as the others. The dilution of the pinkish male is proportionally greater than that of the pinkish female. It is just in this respect that eosin itself differs from the cther eye colors. The combination of these two 'sex-limited' characters, both of which differ in the same direction, increases the sexual dimorphism of the flies to a striking extent.

Specificity. The primary characteristic of all these modifiers is that their visible effect upon eye color is dependent entirely upon, or is greatly increased by, the coaction of eosin. Of the eight modifiers, six (creams a, II, b, c, dark, and whiting) are entirely dependent, giving no visible effect whatever in the absence of eosin, while pinkish gives a very slight dilution and cream III gives a dilution which is strong enough so that by avoiding certain adverse conditions there is the possibility of using it without the complication of eosin. In the case of pinkish the dilution is so slight that only in about a third of the flies is there any detectable difference. With both cream III and pinkish the ease of separation and the sharpness of the difference is vastly greater in the presence of eosin.

The term 'disproportionate modifier' might perhaps be better for such cases as those of cream III and pinkish. Most of our mutations are what may be called 'general modifiers,' since their effects seem to be independent of one another, and the combined effect is cumulative and roughly proportionate. 'General modifiers' may be represented by the familiar parallelogram, in which the initial condition (wild-type) is one comer, the effect of each gene acting independently is represented by the length and direction of the two adjacent sides, and the combined effect (double mutant type) is the opposite corner (diagram 2, a). In the case of the completely specific modifiers, such as cream II, the length 
of the side between the wild-type and (not-eosin) cream II corners is zero, so that the parallelogram becomes reduced to a triangle (diagram $2, \mathrm{~b}$ ). In the case of pinkish and cream III there is an intermediate condition in which the side between eosin and the double type is disproportionately far greater than the distance between the wild-type and the simple modifier (diagram 2, c). There is another type of disproportionate modification exemplified by eosin sepia which might be called reversed.
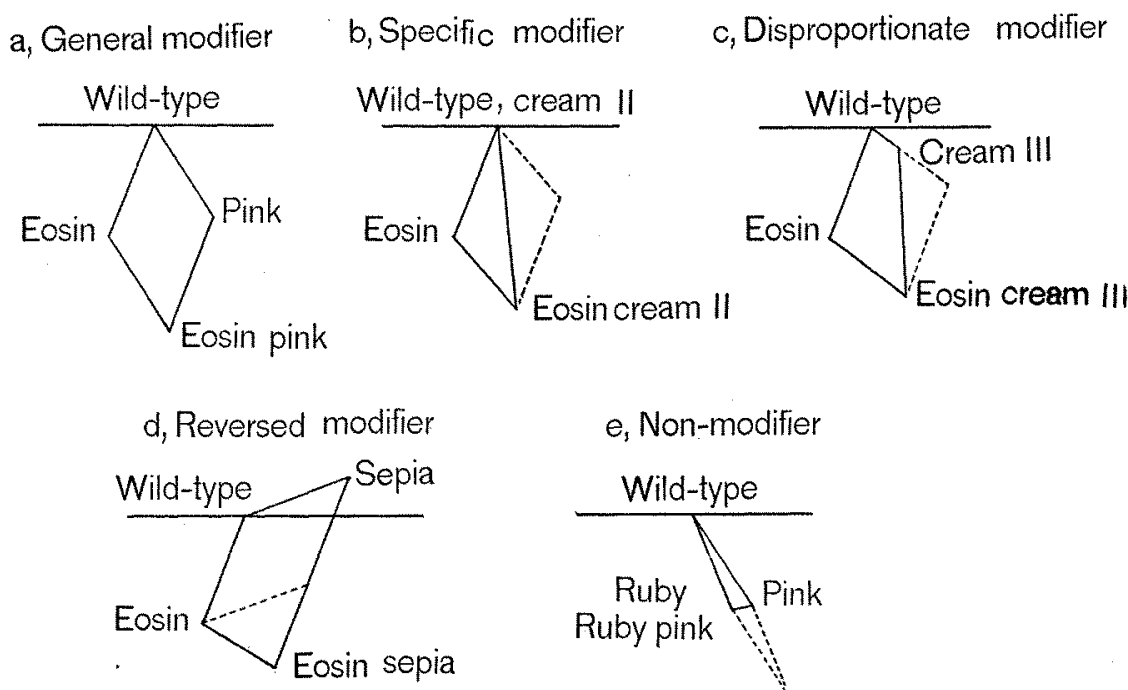

$$
\text { e, Non-modifier }
$$

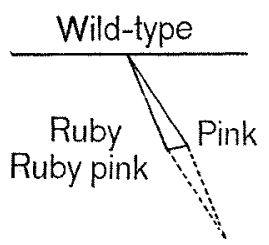

Diagram 2. A graphical representation of some types of modification

Sepia is considerably darker than the wild-type, becoming a deep blue-black in old flies. One might expect that sepia would cause a proportional darkening of eosin so that eosin sepia would be as much darker than eosin as sepia is darker than the wildtype. This is not the condition that actually obtains. The eosin sepia double form is lighter than eosin, about as represented in diagram $2, \mathrm{~d}$. There are several other curious types of disproportionate modification. Thus, for example, ruby (sexlinked) may be described as a 'non-modifier' of pink. The effects of these two genes are in the same direction and of like amount, 
but they fail to have a cumulative effect, the double type being practically indistinguishable from either single type instead of being as much lighter as each is lighter than the wild-type (diagram 2, e).

It has been shown for the case of cream II that specificity of a very extreme nature obtains; since cream II is incapable of modifying any of the other mutant eye colors tried in place of eosin. The double recessives (not-eosin) cream II vermilion, and (not-eosin) cream II pink are the same in eye color as simple vermilion and pink, respectively. In the case of whiting the specificity is even more striking; for cherry, an allelomorph of eosin so similar as to be distinguished (in the females) only with great difficulty, is entirely undiluted by the whiting gene.

Tone. Pinkish is aberrant in still a third respect: the other modifications can all be described as grades of dilution of the yellow-pink color of eosin, the lighter grades being especially dilute in the pink component of the color. Pinkish, on the other hand, gives one the impression that the yellow component has faded more than the pink, so that there remains a slightly greater proportion of pink in pinkish than in eosin or in the other modifications.

Dominance. The only one of the modifiers which gives an appreciable effect in heterozygous form is cream II. The amount of dilution of eosin due to heterozygous cream II is of about the same grade that the weakest of the other modifiers, namely, pinkish, gives when homozygous.

Fluctuation. The amount of fluctuation in the eye color of the creams due to differences in age, food, etc., was about the same as that observed in the other eye colors and their combinations. This question is of some practical importance in the making of classifications and is of theoretical interest in connection with the completeness of the seriation obtainable with a relatively few modifiers.

Viability. All of these creams are of excellent viability and the observed ratios are very close approximations to expectation.

Chromosome. Because of the difficulty of putting the modifiers to practical use, it was not at first thought worth while to 
determine in which chromosome the gene for a given modifier lies. This information is therefore lacking in the case of cream a, dark, and whiting. Of the five other modifiers, one, cream III, is in the third chromosome, and the other four are in the second. The presence of four modifiers of eosin eye color in the second chromosome is in contrast to, or perhaps supplementary to, the relative fewness of ordinary eye-color mutations in that chromosome. None of the modifiers were sex-linked, but this is probably not of special significance.

Locus. The locus within the second chromosome has been determined for two of the four second chromosome modifiers of eosin, namely, pinkish at about 106, and eream b at 22.5. The locus of cream III has not been found directly because of the presence of $\mathrm{C}_{\mathrm{III}}$ in the cream III stock. In heterozygous $\mathrm{C}_{\text {III }}$ there has been found to be 4.2 per cent of crossing over between cream III and dichaete, and 5.4 per cent of crossing over between cream III and ebony. This corresponds to a locus on the normal map of about 3.1 units to the left of dichaete or at about 7.9 units to the right of sepia which is the zero-point of the map of the III chromosome.

\section{DISCUSSION}

The facts of the inheritance of these specific modifiers show that each is a definite Mendelian gene on the same footing with the whole body of genes known in Drosophila. Thus, they display clean-cut segregation from their allelomorphs; each is located in and transmitted by a specific chromosome of the Drosophila complex; they give free assortment with genes located in other chromosomes; and with genes located in the same chromosome they show linkage, with crossing over corresponding to a fixed locus. Each of these genes arose by mutation-" "a specific change in the hereditary constitution"--by the transformation of the materials of a particular locus into a new form having a different effect upon the developmental processes.

These specific modifications are clear and simple cases of 'multiple genes.' Each is the result of the coaction of a specific 
modifying gene (cream $a, b$, etc.), which by itself produces little or no visible effect, and of a particular gene (eosin) that is necessary as a 'base' or 'differentiator.'

The scale of the modifications of eosin produced by these several modifiers ranges on the one hand to a deep pink darker than eosin, and on the other hand to a pure white. This scale is purely artificial and descriptive, for these modifiers were entirely independent of one another in origin. Furthermore, the order of their occurrence bears only a random relationship to the dark-light seriation.

By judicious combination of several such simple modifiers a multiple heterozygous stock could be obtained which would be amenable to selection and which would offer upon analysis a satisfactory parallel to such a case as that shown by Castle's rats. The first result of selection in such a heterogeneous stock in the direction of lighter forms would be to pick out individuals homozygous for one or more of the modifiers and probably heterozygous for others. These different individuals of course would not necessarily be homozygous for the same factors, and therefore the population might still remain heterogeneous for these factors. Continued selection would result in a greater and greater degree of homozygosity and homogeneity and a consequent slowing down of the speed of the progression of the population in the direction of selection. The grade of the form reached when the population is homozygous and homogeneous would depend on the number and character of the particular modifiers in the initial population.

The fact must not be lost sight of that there is not one iota of evidence to show that either the rate or the direction of the mutation processes that are characteristic of the species are altered by such selection. During the course of any selection experiment modifiers and other mutations should arise at the normal rate. In Drosophila roughly 25 per cent of the mutations found were wing or venation characters, 16 per cent body-color characters, and 20 per cent eye colors. Only eye-color mutations would have any effect upon the progress of our selection. The eye-color mutations found in Drosophila have been roughly in 
the proportion of 60 per cent of general or non-specific modifiers of eosin, such as vermilion and pink, 22 per cent specific modifiers of eosin, and 18 per cent allelomorphs of eosin. The proportion in which mutations are found should, of course, be distinguished from the proportion in which mutations arise. In this particular example the difference should be considerable, for since all the flies are eosin, the situation is particularly favorable for the detection of specific and disproportionate modifiers of eosin, and the percentage found should be correspondingly higher than in our general work where eosin flies constitute only a small fraction. It is probable that mutation is very much more frequent than appears, since a great many mutations are of very slight somatic effect and would pass undetected except that certain characters, such as eosin eye color, truncate wings, beaded wings, and a few others, are peculiarly sensitive differentiators for eye-color and wing-shape genes, etc. Mutations capable of affecting eye color, wing shape, etc., are presumably not less frequent of origin in ordinary stocks, such as pink eye or rudimentary wings, but these latter are poor reagents for the detection of mutations. Whether or not a specific modifier should arise during the course of selection depends on the length of the selection, that is, on the number of individuals, as well as on the frequency of that type of mutation.

The previous eye colors (all types) may be roughly classified as 90 per cent dilutors and 10 per cent darkeners of eye'color which is about the same proportion as that found among the specific modifiers themselves. Cases like that of eosin sepia show that the ratio of darkeners to dilutors considered from the basis of eosin may be far different from that shown by the primary effects of these same genes (differences from the wild-type). Whatever this normal ratio for eosin is, it should obtain in the selection experiment as well. When mutation in the direction of selection occurs, there should be a jump in the speed of progression, and the final grade should be correspondingly more extreme. However, the modifier might be a darkener, but in that case it would not be selected and consequently would have only negligible effect upon the speed and the resultant grade. 
No one can deny that progress under selection is theoretically possible by repeated mutation in a single locus. But to accept that as the actual mode in any particular case demands specific proof. Such a hypothesis should not be considered until it has first been demonstrated that the initial constitution of the stock was such as to require the assumption of further acts of mutation. If a fresh act of mutation is required, then adequate proof must be submitted before it can be accepted that this mutation is in the particular locus favored rather than in one or another of the numerous other possible loci. Our experience with many cases of successful selection in Drosophila has been that even in this form, where the work is aided by such special features as a very small number of chromosomes, by absence of crossing over in the male, and by a knowledge of the initial constitution of the stocks that is not paralleled in other forms, it is often a matter of some difficulty to prove that a particular modification arose during the course of an experiment rather than that it was present in and introduced through one of the parents. How much more difficult, then, would it be to prove in a form where the tests are far less precise and on a relatively small scale that all progress observed during the course of selection is due to the occurrence step by step of fresh mutations? And how much more precarious would it be to affirm that these fresh mutations are all of a single locus, when one remembers that there are probably hundreds or even thousands of loci in which a mutation would have effect upon any given character. The evidence in the case of the creams is diametrically opposed to such a type of explanation, since the creams are manifestly of discontinuous origin in as many distinct loci as there are diverse modifications. The similarity between the creams and such a case as that of the rats must be attributed to the presence in the rats of the only condition met with in the creams, namely, diverse mutation.

In the absence of rigorous tests, no one is justified in assuming that modifiers are not present in any given stock. Not only have the many selections carried out on Drosophila led experimentally to such a conclusion, but it follows from a consideration of the facts of mutation. In the carefully pedigreed experi- 
ments of Drosophila we continually observe mutations arising, and are often able to locate the time and place of origin to a particular fly and to within one or a few cell generations. Everyone who believes that mutations are now occurring in his stocks in this manner must also accept the probable occurrence of such mutations in the immediate ancestry of his stocks, since it is not likely that either the rate or tendency of mutation have changed within any period with which we deal. The process of mutation thus gives rise in any stock to a complexity and heterogeneity which is only that 'static condition of diversity' said by Jennings (Jennings, '17) to obtain for any species or kind of organism, such, for example, as the hooded rat. When selection is started in such a stock immediate progress should be expected and this should continue until the stock is homozygous for all the genes capable of modifying the selected character. One cannot be certain that observed progress is due to fresh mutation until selection has been continued long enough so that the initial diversity has been removed. The initial diversity means that mutations had previously occurred in various loci, and the presumption is that during the progress of selection the stock will not cease mutating in diverse loci and henceforth mutate solely in one locus. Muller ('14), MacDowell ('16), Sturtevant ('18), and others have shown that the results obtained with selection in the hooded rats are, aside from one definite new mutation, exactly those expected from simple selection, in a heterogeneous stock of the kind supposed by the Frenchman Jordan, subscribed to by Jennings, and easily explained as the result of previous diverse mutations. It is interesting to observe that the list of cases in which unilocal mutations or contamination may be seriously considered is dwindling with the progress of exact knowledge.

In our opinion, the attempted distinctions between 'saltations,' 'mutations,' and 'variations of slight degree' have led rather to confusion of thought than to clearer thinking. To us these are all a single class, 'mutations,' and the term carries no restrictions of degree, covering the most extreme as well as the slightest detectable inherited variation. Distinctions of degree when ap- 
plied to mutations depend largely on circumstances and personalities, and are correspondingly inexact. Thus, students beginning work on Drosophila usually complain that there is almost no difference between pink eye color, for example, and the wild form, so that the classifications are made with considerable uncertainty. With more experience these same workers come to regard this difference as very great and are astonished that they should ever have thought otherwise. Again, some workers are able to distinguish with assurance characters that quite pass the resolving power of other workers seemingly equally experienced.

In the Drosophila work great numbers of mutations have been encountered whose somatic effect may be roughly described as 'slight.' If degree of effect were marked off as abscissae and number of mutations that actually arise as ordinates, it seems probable that the highest point of the curve would be at the least extreme mutations and the curve would fall rapidly and gradually with the most extreme mutations. For most of the problems in which we have been interested precision of classification is essential, and precision is afforded only by the more extreme mutations and by some few of slight degree but definite character. Accordingly, there has been scant mention of the many 'slight' mutations in our accounts, which have dealt in the main with problems in which such characters were of no use as working tools. Likewise, when these mutations are found, they incite little desire to work out the facts concerning their inheritance, chromosome, locus, interactions, etc. However, enough of them have been investigated thoroughly for us to be certain that no departure from normal Mendelian inheritance is involved. Accounts of some of these 'poor' characters have appeared in Carnegie Publication no. 237, which deals with mutants whose locus is in the first or X chromosome. Thus, for example, dot, bow, depressed, green, chrome, and facet may all be fairly described as of 'slight' somatic effect. Accounts of many others will appear in the publications dealing with the second, third, and fourth groups. Even a larger number will be treated in a section on miscellaneous mutations, while scores will never be referred to at all. 
It seems probable that the bulk of the mutations that have been permanent contributions to evolution have been those of slight somatic change. Any organism as it now exists must be regarded as a very complex physicochemical machine with delicate adjustments of part to part. Any haphazard change made in this mechanism would almost certainly result in a decrease of efficiency. The greater the extent of the change the more certain the injury, not simply that the particular part is injured more, but also that a disproportionately greater number of adjustments (morphogenetic, physiological, and ecological) are disturbed or destroyed. Only an extremely small proportion of mutations may be expected to improve a part or the interrelation of parts in such a way that the fitness of the whole organism for its available environments is increased. Thus, that length of trunk which is most advantageous for elephants in a given environment might be attained by a single mutation; but in this case it is likely that the trunk would be out of balance with the other structures (physiologically or otherwise) so that all the individuals possessing this feature might become extinct before the appearance of changes in these other parts that would make the trunk a real success. On the other hand, a mutation which made only a slight change in the favorable direction would require less extensive supporting changes in the related structures, besides which it might be of immediate advantage. 


\section{LITERATURE CITED}

Bridars, C. B. 1916 Non-disjunction as proof of the chromosome theory of heredity. Genetics, vol.1, pp. 1-52, 107-163.

Bridges, C. B., and T. H. Morgan. 1919 (in press). The second chromosome group of linked genes. Carnegie Inst. Pub. no. 287, part II.

Bridges, C. B., AND A. H. STurtevant. 1914 A new gene in the second chromosome of Drosophila and some considerations on differential viability. Biol. Bull., vol. 26, pp. 205-212.

Castle, W. C., and J. C. Phillips. 1914 Piebald rats and selection. Carnegie Inst. Pub. no. 195,56 pp., 3 plates.

Jennings, H. S. 1917 Observed changes in hereditary characters in relation to evolution. Jour. Wash. Acad. Sci., vol. 7, pp. 281-301. 1917 Modifying factors and multiple allelomorphs in relation to the results of selection. Am. Nat., vol. 51, pp. 301-306.

MacDowelt, E. C. 1916 Piebald rats and multiple factors. Am. Nat., vol. 50, pp. 000-000.

Merz, C. W. 1914 An apterous Drosophila and its genetic behavior. Am. Nat., vol. 48 , pp. $674-711$.

Morgan, T.H. 1912 Further experiments with mutations in eye color of Drosophila. The loss of the orange factor. Jour. Acad. Nat. Sci. Phil., vol. 15 , pp. 321-346.

1915 The role of the environment in the realization of a sex-linked Mendelian character in Drosophila. Am. Nat., vol. 49, pp. 385-429.

1916 A critique of the theory of evolution. Princeton University Press, $195 \mathrm{pp}$.

Morgan, T. H., AND C. B. Bridges. 1913 Dilution effects and bicolorism in certain eye colors of Drosophila. Jour. Exp. Zool., vol. 15, pp. 429-466. 1916 Sex-linked inheritance in Drosophila. Carnegie Inst. Pub. no. 237,87 pp. +2 plates.

Morgan, Sturtevant, Muller and Bridges. 1915 The Mechanism of Mendelian heredity. Henry Holt \& Co., 262 pp.

Muller, H. J. 1914 The bearing of the selection experiments of Castle and Phillips on the variability of genes. Am. Nat., vol. 48, pp. 567-476.

1914. The mechanism of crossing over. Am. Nat., vol. 50, pp. 193-221, 284-305, 350-366, 421-434.

Sturtevant, A. H. 1913 A third group of linked genes in Drosophila ampelophila. Science, vol. 37, p. 990.

1918 An analysis of the effects of selection. Carnegie Inst. Pub. on. 264,67 pp. +1 plate.

1919 (in press) Inherited linkage variations in the second chromosome. Carnegie Inst. Pub. no. 287, part III. 